\title{
A 2000-2015 KÖZÖTTI CSALÁDPOLITIKAI INTÉZKEDÉSEK HATÁSA A SZÜLETÉSSZÁMRA MAGYARORSZÁGON*
}

\section{Bördős Katalin - Szabó-Morvai Ágnes}

\section{ÖSSZEFOGLALÓ}

Elemzésünkben a 2000 és 2015 közötti családpolitikai támogatások és intézkedések fertilitásra gyakorolt hatását vizsgáljuk, melyet FH panel regressziókat használunk. Eredményeink azt mutatják, hogy a családtámogatási rendszer azon elemei vannak a legnagyobb hatással a termékenységre, amelyek a foglalkoztatási, a megélhetési és a lakhatási lehetőségeket javítják. A nők jelenlegi foglalkoztatottsága, a bölcsőde és az óvoda elérhetősége és a részmunkaidős munkalehetőségek jelentősen növelik a tisztított élveszületési arányszámot, mely különösen igaz az első gyermek esetében. A családtámogatási rendszer egészét tekintve a hazai beavatkozások hasonló eredményességet mutatnak, mint a többi országban: enyhén pozitív, szignifikáns hatással vannak a termékenységre. A kapott eredmények arra utalnak, hogy a foglalkoztatás és a bérek növelését célzó gazdaságpolitikák valószínűleg a leghatékonyabb termékenységi politikák közé tartoznak. Ugyanakkor az eredmények azt is megmutatták, hogy a megfizethető lakhatás kulcsfontosságú tényező, amit nem csupán saját lakás vásárlását elősegítő támogatásokkal, hanem a bérlakáshoz jutást segítő programokkal is lehetne támogatni.

\footnotetext{
* A cikk alapját képező számításokat az Európai Bizottság Magyarországi Képviselete megbízásából készítettük el 2018 2019-ben. A szerzők köszönetet mondanak a Központi Statisztikai Hivatal és a Közgazdaság-és Regionális Tudományi Kutatóközpont Adatbankjának és a magyar államigazgatásnak az adatok hozzáférhetővé tételéért. Hálásak vagyunk Gyulai Ágnesnek az asszisztensi munkájáért, valamint Gál Róbertnek és Csillag Mártonnak az építő megjegyzésekért, Horváth Áronnak és az ELTINGA Ingatlanpiaci Kutatóközpontnak az ingatlan adatokért. Szabó-Morvai Ágnes munkáját az FK-131422 számú pályázata támogatta.
} 
Tárgyszavak: gyermekvállalás, családpolitika

Bördős Katalin, HÉTFA Kutatóintézet

E-mail: bordoskatalin@hetfa.hu

Szabó-Morvai Ágnes, KRTK KTI, Debreceni Egyetem

E-mail: szabomorvai.agnes@krtk.hu

\section{BEVEZETÉS}

Az európai országok számára jelenleg az egyik legnagyobb középtávú kihívást a csökkenő gyermekszám, és az ennek következtében beálló demográfiai krízis jelenti. Magyarország ebben a tekintetben hasonló problémákkal küzd, változatos szakpolitikai eszközök alkalmazásával kívánja ösztönözni a születendő gyermekek számának növekedését. A magyar termékenységi ráta 1975 óta majdnem folyamatosan csökkent, míg 2011-ben érte el a minimumát (1,23). Ezt követően mérsékelt emelkedést mutatott, és 2019-ben elérte az 1,49 értéket, ami csupán kevéssel maradt el az EU átlagtól (1,52).

Becker (1960) modellje szerint a fertilitási döntések során a családok a gyermekvállalással járó anyagi és nem anyagi hasznokat vetik egybe a költségekkel. Spéder és Kapitány (2007) ugyanakkor rávilágít arra, hogy az első gyermek vállalását egészen más tényezők befolyásolhatják, mint a későbbi gyermekekét. A gyermekhez füződő anyagi terhek csökkentését célzó szakpolitikai intézkedéseket számos cikk vizsgálta (Ermisch, 1988; Greulich, Thevenon and Guergoat-Lariviere, 2015; Zhang, Quan, and van Meerbergen, 1994). Ezek közül több is demonstrálta azt a bizonytalanságot, hogy ezen szakpolitikák a befejezett fertilitást, vagy csak a gyermekvállalás időzítését befolyásolják. Francia adatokat vizsgálva Laroque and Salanié (2008) azt találja, hogy ha az éves GDP 0,3\%-ának megfelelő költségvetésből bevezetnének egy mindenki által igénybe vehető gyermeknevelési támogatást, az 0,3mal növelné meg a termékenységi rátát. Gábos et al. (2009) szerint a családi támogatások 1\%-os növelése 0,2\%-kal emelné a termékenységet. Ang (2015) számításai szerint 2008-ban Kanadában 15 ezer kanadai dollárral kellett volna megemelni a családi támogatást, vagy 223 ezer dollárt kellett volna kész- 
pénzes támogatásként adnia ahhoz, hogy átlagosan eggyel nőjön a született gyermekek száma'.

A hazai szakpolitikai környezetben egyetlen intézkedés változásának termékenységi hatását mérni komoly módszertani kihívást jelent. A kvázi-kísérleti módszerek például kudarcot vallhatnak, mivel a családi adókedvezmények hirtelen emelkedésére adott válaszreakcióként a termékenységi ráta valószínűleg nem ugrik meg rögtön. Továbbá egy 1-3 hónapos megfigyelési időszak alatt sem mutat jelentős változást. Inkább fokozatosan alkalmazkodik egy hosszabb, legalább 9 hónapos, de valószínűleg inkább 1-3 éves időszakon keresztül. Ez azt eredményezné, hogy a becsült hatások nullák lennének a szakpolitikai változás szűk időkörnyezetében. Ennélfogva egyetlen családpolitikai intézkedés hatásbecsléséhez egy hosszabb időszak adatait kell felhasználni. Ezzel a megközelítéssel viszont az a probléma, hogy Magyarországon úgy, mint több másik EU országban is, a családpolitikai rendszer számos eleme változik néhány éves távlatban, s ezek egyenként különféle hatással lehetnek a termékenységi rátára. Emiatt a családpolitikai rendszer elemeit célszerü egyben elemezni, hogy elkerüljük a kihagyott változók miatti torzítást.

Ebben a cikkben mindazoknak a szakpolitikai intézkedéseknek a tisztított élveszületési arányszámra (TÉA) gyakorolt hatását elemezzük, amelyek ezt elsődleges célként tűzik ki, vagy csupán mellékhatásként befolyásolják a születésszámot. A méréshez használt adatbázis termékenységi és demográfiai háttérinformációkat tartalmaz a 2000 és 2015 közötti évekre vonatkozóan, amelyeket NUTS3 régiók, településtípus, az anya életkori kategóriája (10 éves bontásban), iskolai végzettsége és munkaerő-piaci státusza szerint alkotott csoportokra aggregáltunk. Ezen dimenziók mentén adatbázisunkban a népesség és a családtípusok is kategorizálva vannak, közel 10 ezer cellában. Továbbá a 2000 és 2014 között bevezetett családpolitikai intézkedéseket szintén rögzítettük az adatbázisban, így megjelennek az egyes családtípusok számára potenciálisan elérhető ösztönzők, típusonként és összesítve is.

Cikkünkben egy speciális aggregált adatbázist használunk a hatások becslésére, melyet a KSH Élveszületési Adatbázis, a KSH Demográfiai Évkönyv, a KSH Munkaerő-felmérés (MEF) és az ÁFSZ Bértarifa felvétel adatai alapján állítottunk össze. Az elemzésben fixhatás panel modellekkel mérjük a család-

\footnotetext{
${ }^{1}$ A szerző a hatásbecslés nagyságát a könnyebb interpretáció kedvéért átszámította arra, hogy mennyit kell költenie az adott családtámogatási programra a kormánynak átlagosan ahhoz, hogy eggyel több gyermek szülessen meg az országban. Ehhez kiszámította az értékelt családtámogatási program egy nőre jutó költségét, illetve ezt elosztotta a program által kiváltott fertilitás változás mértékével.
} 
politikák együttes és különálló hatásait, a születési sorrend szerinti hatásokat, illetve a születés bármely sorrendjének átfogó hatását, továbbá 1, 2 és 3 éves késleltetéssel mérjük a szakpolitikák hatását is. A regressziós eredmények megmutatják, hogy az első és második gyermek születését pozitívan befolyásolják a foglalkoztatási lehetőségek, a rugalmas munkalehetőségek elérhetősége és a bölcsődei, óvodai ellátottság. A harmadik születésre pedig negatívan hat az anyák foglalkoztatottsága. Az eredmények azt mutatják, hogy a magasabb pénzbeli családi juttatások késleltetik az első születést és enyhén növelik a harmadikat.

A családpolitikák részletes elemzése során az első és a harmadik év között háromféle családpolitikai intézkedés esetében találtunk szignifikáns pozitív hatást. A többi szakpolitikára vonatkozóan nem találtunk statisztikailag szignifikáns hatásokat.

\section{ELMÉLETI MODELL}

A termékenység modellezéséhez egy egyszerű valószínűségi modellt használunk (Id. pl. Das, 2019, o. 89). Ha egy újabb gyermek vállalásának nettó értéke pozitív, a család a gyermekvállalás mellett dönt. A szülők a jövedelemkorlát figyelembevételével maximalizálják a hasznosságot:

$$
\max _{B_{i}}\left\{U\left(B_{i}\right): I=C+T_{i}\right\}
$$

ahol U(B.) az i-edik gyermek vállalásából eredő hasznosság, amely lehet bármilyen pszichológiai haszon (a gyermekvállalás közvetlen haszna), anyagi haszon (pl. gyermekkel kapcsolatos támogatások), illetve reciprocitáshoz füződő várakozások (pl. a gyermekektől kapható majdani öregkori transzferek). A család jövedelme I, C a háztartás egyéb javakra és szolgáltatásokra fordított fogyasztása (beleértve a családban már meglévő gyermekekre fordított kiadásokat), Ti pedig a további gyermekhez kapcsolódó közvetlen (pl. egészségügyi, ruházati, oktatási stb. kiadások) és közvetett (pl. az anya elmaradt jövedelme) költségek összege. A modellben feltételezzük, hogy a szülők ki tudják számítani az összes élethosszig tartó haszon és költség jelenértékét. A szülők gyermekvállalási döntése attól függ, hogy egy újabb gyermek vállalása növeli-e a háztartás nettó hasznát.

Még egy gyermeket vállalnak, ha $U\left(B_{i}=1\right)-U\left(B_{i}=0\right) \geq 0$ és nem vállalnak, ha $U\left(B_{i}=1\right)-U\left(B_{i}=0\right)<0$, ahol $B_{i}=1$, ha a szülök úgy döntenek, hogy még egy gyermeket vállalnak. 
A modellt látens változós modellben becsüljük. Legyen $Y_{i}^{*}$ a nem megfigyelhető látens változó, amelyet a következőképpen határozunk meg:

$$
Y_{i}^{*}=U\left(B_{i}=1\right)-U\left(B_{i}=0\right)
$$

ahol $B_{i}$ egy bináris változó, amelyben $B_{i}=1$, ha a családban további gyermek születik és $B_{i}=0$, ha nem. A döntés a következő lesz:

$$
B_{i}= \begin{cases}1, & Y_{i}^{*} \geq 0 \\ 0, & Y_{i}^{*}<0\end{cases}
$$

A becsült egyenlet a következőképpen írható le:

$$
\operatorname{Pr}\left(B_{i}=1 \mid X_{i}\right)=\operatorname{Pr}\left(Y_{i}^{*} \geq 0 \mid X_{i}\right)=\operatorname{Pr}\left(\beta_{0}+\sum_{n} \beta_{n} \cdot X_{n i}+\epsilon_{i} \geq 0\right)
$$

ahol $n \in \mathbb{Z}$.

Az $X_{n i}$ minden olyan tényezőre kiterjed, amely befolyásolja a további gyermek előnyeit és költségeit, mint például a szülők végzettsége vagy az adott évben elérhető gyermektámogatások összege. Ily módon egy olyan modellt írunk fel, amely valószínúségi modellel mérhető, a hibatag $\left(\epsilon_{i}\right)$ eloszlására vonatkozó megfelelő előfeltevéssel.

\section{ADATOK}

Az adatbázisunkban különböző forrásokból származó, egyéni szintủ adatokat használtunk fel, amelyeket év és „nőtípus” cellákba aggregáltunk. A nőtípus meghatározása a következők alapján történik: 1.) a nő lakóhelye (településtípus és megye szerint); 2.) a nő életkori kategóriája 10 éves sávokban; 3.) a nő legmagasabb iskolai végzettsége (gimnáziumi végzettséggel rendelkezik vagy sem)2; 4.) munkaerő-piaci státusz (foglalkoztatott vagy nem foglalkoztatott). A kategóriák pontos leírása megtalálható az 1. táblázatban. A végleges adatbázis 9984 cellát tartalmaz 16 évre vonatkozóan, ami azt jelenti, hogy minden évben 624 „nőtípus” cella található.

A függő változó az adott cellában számított termékenységi ráta. A termékenységi rátákat úgy határoztuk meg minden egyes cellára, hogy a születések számát elosztottuk a nők számával. Mivel sem a számlálóra, sem a nevezőre vonatkozó adatok nem állnak nyilvánosan rendelkezésre ezekhez az aggregátumokhoz és nem létezik olyan mikroszintủ adatbázis sem, amely minden szükséges információt tartalmaz, ezért három mikroszintű adatforrásra volt szükség a megfelelő adatok eloállitásához.

\footnotetext{
${ }^{2}$ A kategóriák finomságát a béradatbázisban szereplő megfigyelések száma korlátozza. Ahhoz, hogy növelni tudjuk a megfigyelések számát az egyes nőtípusok celláiban az iskolai végzettséget két kategóriába kellett összevonnunk.
} 
1. tábla: Cellák meghatározása

\begin{tabular}{|c|c|c|}
\hline Változó & Kategóriák száma & Értékek \\
\hline Év & 16 & $2000-2015$ \\
\hline $\begin{array}{l}\text { Lakhely- } \\
\text { megye }\end{array}$ & 20 & NUTS-3 szintü terület: 19 megye + Budapest \\
\hline $\begin{array}{l}\text { Lakhely- } \\
\text { település }\end{array}$ & $\begin{array}{c}3 \\
\text { (1 Budapesten és } \\
2 \text { a többi megyében) }\end{array}$ & $\begin{array}{l}\text { Község / város / főváros (Budapest) } \\
\text { (alkalmazkodva a magyar közigazgatási és jogi kifejezésekhez) }\end{array}$ \\
\hline A nő kora & 4 & $\begin{array}{l}10 \text { évenkénti csoportok (5 évenkénti csoport az alacsonyabb } \\
\text { életkornál): 15-19 / 20-29 / 30-39 / 40-49 év }\end{array}$ \\
\hline $\begin{array}{l}\text { A nő iskolai } \\
\text { végzettsége }\end{array}$ & 2 & $\begin{array}{l}\text { Alacsony (nincs felső vagy középfokú végzettsége / } \\
\text { 0-2 ISCED szint) / magas (minimum felső vagy középfo- } \\
\text { kú végzettsége van / } 3 \text { vagy magasabb ISCED szint) }\end{array}$ \\
\hline $\begin{array}{l}\text { A nő munkaerő- } \\
\text { piaci státusza }\end{array}$ & 2 & $\begin{array}{l}\text { Foglalkoztatott / Nem foglalkoztatott (munkanélküli vagy } \\
\text { inaktív) }\end{array}$ \\
\hline Cellák száma össz & $6 * 19^{*} 2^{*} 4^{*} 2 * 2$ (meg & + 16*4*2*2 (főváros) = 9.984 \\
\hline
\end{tabular}

Forrás: saját szerkesztés.

A születések számára vonatkozó információk esetében a KSH Élveszületési Adatbázisára támaszkodunk. Az Élveszületési Adatbázis az 1971 és 2016 közötti összes születési eseményt tartalmazza, emellett nagyon részletes demográfiai adatok szerepelnek az anyáról, mint például az iskolai végzettség, a gyermekek száma, foglalkozás, munkaerő-piaci státusz, a születés pontos dátuma, az anya lakóhelyének irányítószáma, családi állapot, az anya életkora, az apa életkora, az apa iskolai végzettsége és az apa foglalkozása. Az adatbázis az egyes születési események paritására vonatkozó információkat is tartalmazza (hányadik gyermekként született a gyermek).

A cellákban lévő nők száma a KSH Demográfiai Évkönyv adatai alapján kerültek meghatározásra, amelyben az egyes lakóhelyekre (településekre) vonatkozóan, adott korban lévő férfiak és nők pontos számáról, a tényleges lakosok számáról található információ. Nem tartalmaz azonban adatokat a lakosok iskolai végzettségére és munkaerő-piaci státuszára nézve. Ezért a cellákban lévő nők számának kiszámításához meg kell becsülni a különböző iskolai végzettségi szintek arányát, valamint a foglalkoztatott és nem foglalkoztatott nők arányát. Ehhez a KSH Munkaerő-felmérést használjuk: először a MEF adatai alapján kiszámítottuk az egyes 
cellákban lévő nők iskolai végzettségi szintjének és foglalkoztatási státuszának együttes megoszlását, majd ezen arányok segítségével beosztjuk a Demográfiai évkönyv adott cellájába tartozó nőket a megfelelő „nőtípus” cellába.

A családpolitikai adatbázis változói minden évben a nők (és családok) többféle támogatásra és ellátásra való jogosultságán alapulnak. Ezen ellátások tényleges igénybevételére vonatkozó adatokkal is rendelkezünk, de mivel az igénybevételi arányt már befolyásolja a termékenységi ráta, ezért azt nem vesszük figyelembe az elemzésben, hanem a szakpolitikai mix szándékolt (intent-totreat) hatásait számoljuk ki.

Pontosabban, figyelembe véve a jogosultsági szabályokat, a maximális időtartamot és az egyes ellátások törvényben meghatározott összegét, kiszámítjuk, hogy ha egy anya egy adott évben szülne, akkor milyen összegre számíthatna az újszülött gyermek 18. születésnapjáig. A számításnál feltételezzük, hogy a jogosultsági szabályok, az ellátások maximális időtartama és összege (valamint a nő lakóhelye, az iskolai végzettsége és a foglalkoztatási státusza) a következő 18 évben változatlan marad. A nettó jelenérték kiszámításához 3\%-os diszkontrátát alkalmazunk. A 2. táblázat összefoglalja, hogy a modellben mely ellátásokat vesszük figyelembe.

Mivel a fenti juttatások közül néhányat (különösen a CSED-et és a GYED-et) csak foglalkoztatott szülők igényelhetnek és összegük a korábbi munkajövedelemtől függ, a nettó jelenérték kiszámításához minden egyes „foglalkoztatott” munkaerő-piaci státuszú cellára meg kellett becsülnünk az átlagos munkajövedelmet. Ehhez az ÁFSZ Bértarifa felvétel adatbázist használtuk. Ez az adatbázis a 2000 és 2016 közötti évekre vonatkozó részletes adatokat tartalmaz a munkavállalói bérekről, beleértve az évet, a nemet, a lakóhelyet, az iskolai végzettséget, a foglalkozást (FEOR kódot) és az életkort. (Ez az adatbázis nem tartalmazza a jövedelmeket, következésképpen az elemzésben a jövedelmek helyett a béreket kellett használnunk.) Így a végleges adatbázisunkban minden egyes cellára kiszámítható a nők imputált bére (valamint a család összes imputált bére). Ezeket az imputált béreket használjuk a CSED és a GYED várható összegének kiszámításához, amelyet a foglalkoztatott anyák kapnak. A CSED és GYED összegének számításakor azzal a feltételezéssel éltünk, hogy az érintett anyák nem mennek vissza annál az adott évnél előírtnál hamarabb dolgozni, amivel elveszítenék az ellátásra való jogosultságukat. 


\section{2. tábla: Családpolitikai adatbázis}

\begin{tabular}{|c|c|c|}
\hline Családpolitikai eszköz & Leírás & Összeg \\
\hline Családi pótlék & $\begin{array}{l}\text { Átalányösszegü, általános ellátás, amely (alapesetben) a } \\
\text { gyermek 18. születésnapjáig jár. Az összeg a gyermekek } \\
\text { számától és a kedvezményezett szülő családi állapotától függ. }\end{array}$ & $\begin{array}{l}\text { A pontos összeg az egyén } \\
\text { jellemzőitől függ. }\end{array}$ \\
\hline $\begin{array}{l}\text { Gyermekgondozást } \\
\text { segítő ellátás (GYES) }\end{array}$ & $\begin{array}{l}\text { Átalányösszegü, egyetemes ellátás, amely (alapesetben) a } \\
\text { gyermek 3. születésnapjáig jár. }\end{array}$ & $\begin{array}{l}\text { A pontos összeg az egyén } \\
\text { jellemzőitől függ. }\end{array}$ \\
\hline $\begin{array}{l}\text { Gyermeknevelési } \\
\text { támogatás (GYET) }\end{array}$ & $\begin{array}{l}\text { Átalányösszegü, egyetemes ellátás, amely a legfiatalabb } \\
\text { gyermek 18. születésnapjáig jár. Csak nemdolgozó vagy } \\
\text { részmunkaidőben dolgozó, legalább } 3 \text { gyermeket nevelő } \\
\text { anyák jogosultak rá. }\end{array}$ & $\begin{array}{l}\text { A pontos összeg az egyén } \\
\text { jellemzőitől függ. }\end{array}$ \\
\hline Anyasági támogatás & $\begin{array}{l}\text { A gyermek születésekor általánosan járó, } \\
\text { egyösszegű kifizetés. }\end{array}$ & $\begin{array}{l}\text { A pontos összeg az egyén } \\
\text { jellemzőitől függ. }\end{array}$ \\
\hline $\begin{array}{l}\text { Terhességi- } \\
\text { gyermekágyi segély/ } \\
\text { Csecsemőgondozási } \\
\text { díj (TGYÁS/CSED) }\end{array}$ & $\begin{array}{l}\text { A kötelező társadalombiztosítási rendszeren alapuló ellátás, } \\
\text { legfeljebb } 6 \text { hónapig kapható. Csak azok lehetnek jogosultak, } \\
\text { akik korábban már dolgoztak. Az összeg az anya korábbi } \\
\text { munkajövedelmétől függ. }\end{array}$ & $\begin{array}{l}\text { Az egyén jellemzői és a } \\
\text { bér alapján becsült } \\
\text { összeg. }\end{array}$ \\
\hline $\begin{array}{l}\text { Gyermekgondozási dij } \\
\text { (GYED) }\end{array}$ & $\begin{array}{l}\text { A kötelező társadalombiztositási rendszeren alapuló ellátás, } \\
\text { az összeg az anya korábbi munkajövedelmétől függ. } \\
\text { A csecsemőgondozási dijj lejárta után a gyermek második } \\
\text { születésnapjáig tart a jogosultság. }\end{array}$ & $\begin{array}{l}\text { Az egyén jellemzői és a } \\
\text { bér alapján becsült } \\
\text { összeg. }\end{array}$ \\
\hline Családi adókedvezmény & $\begin{array}{l}\text { Kedvezményt biztosít a szülők személyi jövedelemadóiából, } \\
\text { ezáltal növelve a nettó fizetést. A gyermekek számától függ, és } \\
\text { csak a munkaviszonyban álló szülők igényelhetik. } \\
\text { A rendelkezésre álló összeget a családok jövedelemadó } \\
\text { alapja korlátozza, amelyet figyelembe vettünk a szakpolitikai } \\
\text { adatbázisban. }\end{array}$ & $\begin{array}{l}\text { Az egyén jellemzői és a } \\
\text { bér alapján becsült } \\
\text { összeg, minden } \\
\text { évben az aktuális } \\
\text { szabályozásnak } \\
\text { megfelelően. }\end{array}$ \\
\hline $\begin{array}{l}\text { Otthonteremtési } \\
\text { támogatás } \\
\text { (szocpol/LÉT) és } \\
\text { kamattámogatás }\end{array}$ & $\begin{array}{l}\text { A családok számára vissza nem térítendő támogatással járó } \\
\text { rendszer, amelyet saját lakás vásárlására kell felhasználni; } \\
\text { tartalmazhat fix és államilag támogatott kamatozású } \\
\text { kölcsönt is. A támogatás és a kölcsön összege a gyermekek } \\
\text { számától, valamint egyes években a szóban forgó ház vagy } \\
\text { lakás méretétől és állapotától (újépítésű vagy használt) függ. }\end{array}$ & $\begin{array}{l}\text { Részleteket ld. a } 2 . \\
\text { mellékletben. }\end{array}$ \\
\hline $\begin{array}{l}\text { Járulékkedvezmények } \\
\text { (START PLUSZ kártya } \\
\text { /Munkahelyvédelmi } \\
\text { Akció) }\end{array}$ & $\begin{array}{l}\text { A munkabért terhelő alacsonyabb járulékok az anyák } \\
\text { foglalkoztatásának növelése érdekében. }\end{array}$ & $\begin{array}{l}\text { Bináris változók a } \\
\text { rendelkezésre álló } \\
\text { évekre. }\end{array}$ \\
\hline $\begin{array}{l}\text { Első házasok } \\
\text { adókedvezménye }\end{array}$ & Adóalap-kedvezmény az új házaspárok számára 24 hónapig. & Havi 5000Ft \\
\hline $\begin{array}{l}\text { Visszatérés a } \\
\text { munkaerőpiacra }\end{array}$ & $\begin{array}{l}\text { A gyermek azon életkora, amikor az anya először dolgozhat } \\
\text { 1.) részmunkaidőben 2.) teljes munkaidőben anélkül, hogy } \\
\text { elveszitene bármilyen juttatást. }\end{array}$ & $\begin{array}{l}\text { Pontos életkor az ellátás } \\
\text { típusától függően } \\
\text { (GYES vagy GYED). }\end{array}$ \\
\hline $\begin{array}{l}\text { A pénzügyi intézkedések } \\
\text { stabilitása az elmúlt } \\
3 \text { évben }\end{array}$ & & $\begin{array}{l}\text { Részleteket ld. a } 3 \text {. } \\
\text { mellékletben. }\end{array}$ \\
\hline Bölcsődei lefedettség & $\begin{array}{l}\text { Adott területen rendelkezésre álló bölcsődei férőhelyek száma } \\
\text { osztva a } 0 \text { és } 2 \text { év közötti gyermekek számával. }\end{array}$ & \\
\hline
\end{tabular}

a A Családi Otthonteremtési Kedvezményt (CSOK-ot) 2015-ben vezették be, így a jelenlegi adatbázisunkkal nem tudjuk vizsgálni annak hatását. Ehhez még néhány év megfigyeléseit össze kellene gyüjtenünk. Forrás: saját szerkesztés. 
Az adókedvezményt bármelyik szülő igényelheti, illetve megosztható közöttük. Az apák körében sokkal gyakoribb a családi adókedvezmény igénylése, mint a CSED vagy a GYED igénybevétele, ezért nemcsak az anya bérét, hanem a család teljes jövedelmét vettük figyelembe a rendelkezésre álló adókedvezmény összegének meghatározásához. A családi jövedelem kiszámításához minden nőtípussal (cellával) egyesíteni kellett a férj bérének várható értékét. Az imputálás részleteit lásd az 1. mellékletben. A MEF adatbázisban a megfigyelési egység a háztartás, ami lehetővé teszi számunkra, hogy minden nő esetében összekapcsoljuk a partner bruttó bérét, ha egy partnerrel közös háztartásban él (házasság vagy élettársi kapcsolat). Így a családi bruttó bér is megbecsülhető. Minden évre az adott évben aktuális családi adókedvezmény mértékével számoltunk. Feltételeztük, hogy egy család úgy hoz gyermekvállalási döntést, mintha a következő időszakban az adott évre vonatkozó családi adókedvezmény állna fent.

A pénzügyi intézkedések stabilitása mutatóban a pozitív és negatív irányú intézkedéseket szintén figyelembe vettük. A szakirodalom szerint (pl. Aassve, Billari and Spéder, 2006) alapvetően a negatív irányú változások okozta kiszámíthatatlanság eredményez visszaesést a fertilitásban, ugyanakkor a vizsgált időszak családpolitikai expanziós jellege miatt csupán a negatív változások dokumentálása nagyon kis variabilitású mutatót generált volna.

Az adatbázisból minden egyes cellára vonatkozóan néhány további változót is kiszámítunk. Például a partnerek (férjek vagy élettársak) foglalkoztatási arányát, második munkahely meglétének valószínüségét (nő és partner), részmunkaidős foglalkoztatás arányát (nő és partner), szokatlan időpontokban történő munkavégzés arányát (nő és partner) és a házasságkötési arányt. A női foglalkoztatási ráták és a női munkanélküliségi ráták esetében az aggregálás szintje: [Év - Megye - Várostípus - A nő életkora - Családban lévő gyermekek száma - A nő iskolai végzettsége]. Végül a kiegészített munkaerő-felmérés adatait az 1. táblázatban bemutatott aggregációs szintnek megfelelően összevonjuk a mérési adatbázissal.

Az elemzésből kimaradt a 2012-ben bevezetett bölcsődei dijj hatásának vizsgálata, mivel nem álltak rendelkezésre megfelelő mélységű adatok arra vonatkozóan, hogy mely régiókban mekkora összegű volt az átlagos bölcsődei térítési díj. Továbbá az sem látható, hogy mely bölcsődék milyen elvek alapján határozták meg a fizetendő összeget. A GYED Extra egyes lényeges szabályai, mint például a GYED és GYES összegének kumulálhatósága szintén kimaradtak a modellekből, mert a születendő testvérek között eltelt időt nem vettük figyelembe a modellek egyszerüségének és könnyű értelmezhetőségének érdekében. 


\section{LEÍRÓ ELEMZÉS}

Mielőtt rátérnénk a regressziós elemzésre, általános leírást adunk a termékenység hazai alakulásáról. Az aktuális magyar demográfiai helyzetről a legátfogóbb képet a KSH Népességtudományi Kutatóintézet kiadványa a Demográfiai Portré (Monostori, Őri és Spéder, 2018) adja. E tanulmány szerint a születések száma az elmúlt években stabilnak mutatkozott, bár a szülőképes korú nők száma jelentősen csökkent, míg a gyermekvállalási szándék ebben az időszakban nőtt. A teljes termékenységi ráta (TTR) a 2011-es 1,24-ről 1,5-re nőtt. A növekedés az alacsony iskolai végzettségủek és a legfiatalabb korosztályok magasabb termékenységének köszönhető, valamint a kétgyermekes családokban is nőtt a további születések valószínűsége. Ugyanakkor szintén nőtt a gyermektelenek és az egygyermekes családok aránya.

Az 1.e ábra a TTR és a TÉA alakulását mutatja be. A teljes termékenységi ráta az egy nőtől született gyermekek átlagos száma, feltéve, hogy a nő reproduktív életének végéig él és az adott évben számított, életkorhoz kötött termékenységi rátát tapasztalja az évei során. Magyarországon a TTR az elemzésünk időszakában átlagosan 1,31 volt. Ezzel szemben a TÉA az adott évben szülő nők egyszerủ aránya a reproduktív korú nők teljes számához viszonyítva. A TÉA ugyanebben az időszakban átlagosan 3,87\% volt. Amint az 1.e ábrán látható, a TÉA együtt mozog a TTR-rel, így az egész elemzés során ezt használjuk az egyszerüség kedvéért és TÉA-ként vagy termékenységként hivatkozunk rá.

Amint azt az 1.a-d ábrák mutatják, a TÉA összességében nem változott jelentősen a 2000 és 2014 közötti időszakban, azonban a népesség több alcsoportjában jelentős változások következtek be. A különböző várostípusokban a termékenység konvergált: Budapesten növekedett, a falvakban pedig csökkent. Az alacsony iskolai végzettségủek termékenysége fokozatosan csökkent 2010-ig, azután ez a tendencia megfordult. Ezzel szemben a magas végzettségüek csoportjában a termékenység 2008-ig folyamatosan emelkedett, utána viszont csökkent. Az 1.d ábrán két fontos jelenség látható: az egyik a szülő nők átlagos életkorának növekedése, amelyet a húszas korcsoportban a csökkenő termékenység, míg a harmincas korcsoportban megfigyelhető hasonló mértékủ növekedés jelez; a másik pedig a tizenévesek termékenységének meredek emelkedése 2011-től. 
1. ábra: Tisztitott élveszületési arányszám

a) Első-, másod-, harmad-

és magasabb rendủ születések, és összesen
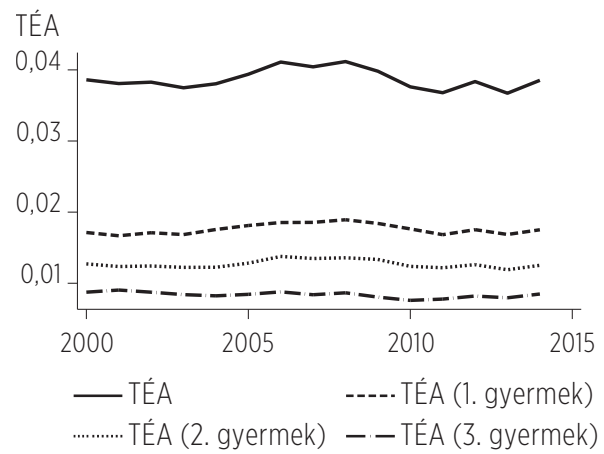

c) A nő iskolai végzettsége szerint

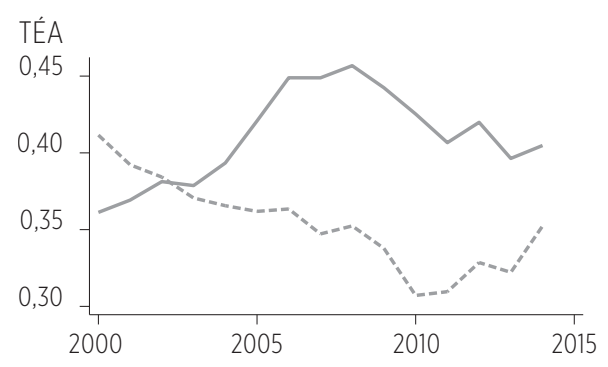

— Magas

----Alacsony

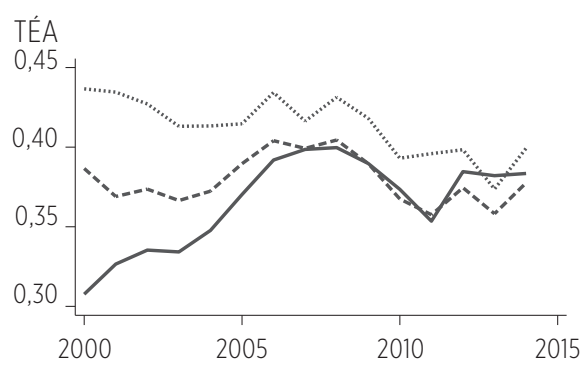

— Budapest -----Város

b) Telepítéstípus szerint

........... Falu

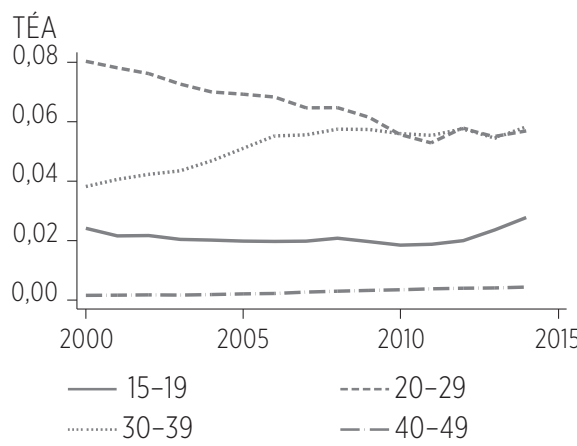

e) TÉA és teljes termékenységi ráta

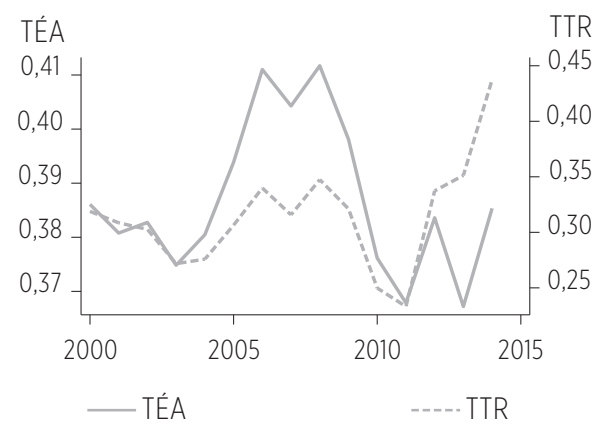

Forrás: saját szerkesztés, a KSH Élveszületési adatbázis alapján. 
A 2. ábra a támogatások átlagos nettó jelenértékét mutatja be, mindezt a jogosultsági kritériumok alapján kiszámítva. Ha egy átlagos 3 gyermekes család az összes elérhető támogatást és juttatást igénybe venné, akkor egy 2000-ben születendő gyermek 18 éves koráig mintegy 10 millió forintot gyűjthetne, feltéve, hogy a szabályozás, a bérek és a támogatások szintje a teljes időszakban változatlan maradna, vagyis az adott évi szabályok maradnának érvényben. A jelenérték-számításokban 3\%-os diszkontrátát feltételeztünk. Minden évben az adott év szabályait alapul véve összegeztük a várható, 18 éves korig gyűjthető támogatási összegeket. Amint az az ábrán is látható, a különböző gyermekszámú családok közötti ék az idő múlásával jelentősen megnőtt.

\section{2. ábra: A támogatások átlagos nettó jelenértéke a jogosultsági kritériumok alapján számitva}

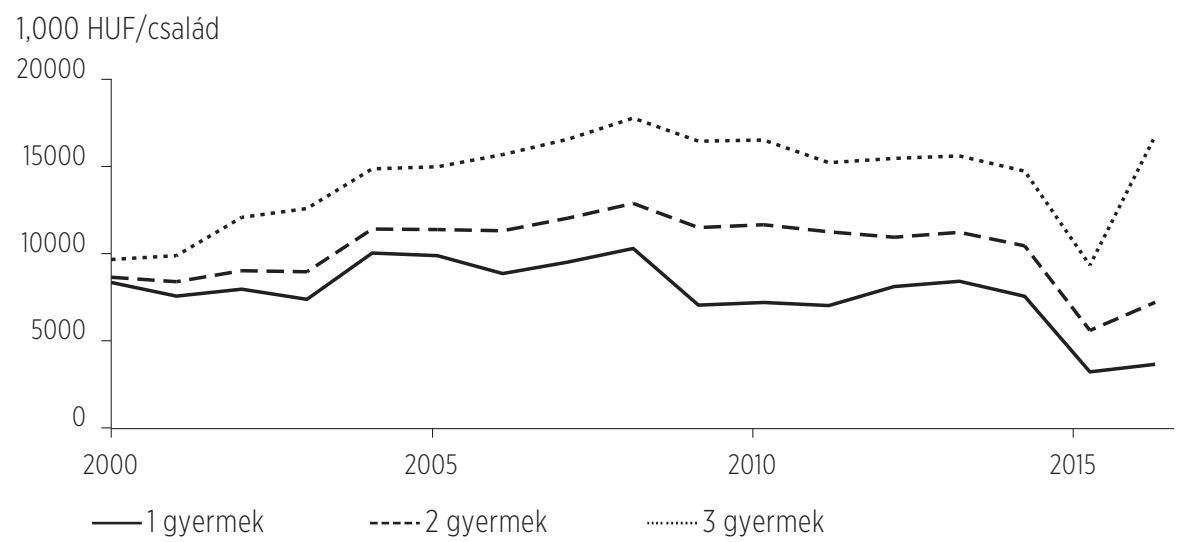

Forrás: saját szerkesztés, az elemzéshez összeállított adatbázis segítségével.

A 3. ábra a termékenység és a bérek kapcsolatát mutatja be. Míg az egyes körök a cellákat ábrázolják, addig a körök mérete az adott cellában lévő népesség méretét fejezi ki. Az ábrák a bruttó átlagbéreket és a termékenységi rátákat mutatják a teljes megfigyelési időszak alatt. A várakozásoknak megfelelően a női bérek növekedése negatívan hat a termékenységre. A magasabb végzettségü nők esetében a 100000 Ft feletti rész releváns. A magasabb végzettségű nőket nézve a férj bére növeli a termékenységet, ami a korábbi szakirodalom alapján szintén várható volt. Az alacsony iskolai végzettségűek termékenysége a férj bére esetén stagnál. A 3. táblázat a legfontosabb változók összefoglaló statisztikáit tartalmazza. 
3. ábra: Bruttó bérek és a TÉA

a) A nő bruttó bére és a TÉA (alacsony iskolai végzettség esetén)

b) A nő bruttó bére és a TEA (magas iskolai végzettség esetén)
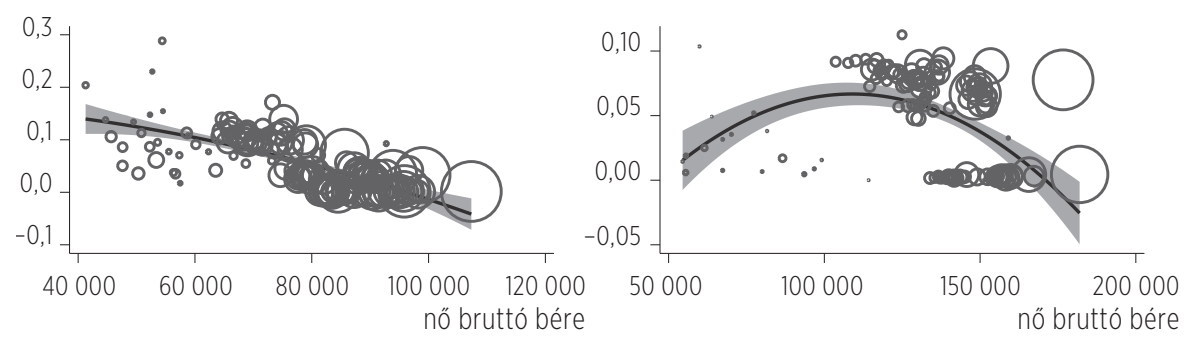

$95 \% \mathrm{Cl}$

- TÉA
- Igazított értékek

95\% Cl

- TÉA c) A partner bruttó bére és a TÉA (alacsony iskolai végzettség esetén) d) A partner bruttó bére és a TÉA (magas iskolai végzettség esetén)
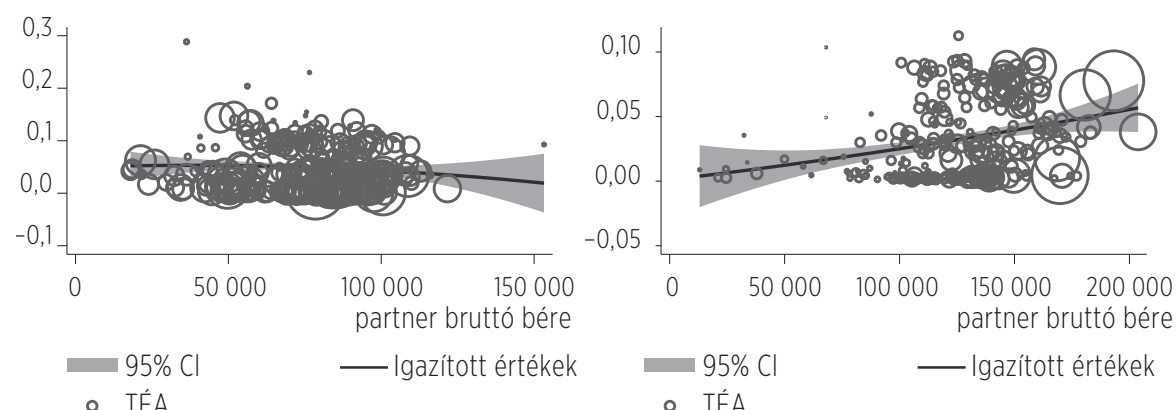

- TÉA

Forrás: saját szerkesztés, az elemzéshez összeállított adatbázis segítségével 
3. tábla: A modell fő változóinak leirró statisztikái (cella átlagok)

\begin{tabular}{|c|c|c|c|c|c|}
\hline Változó & $\begin{array}{l}\text { Megfigye- } \\
\text { lés }\end{array}$ & Átlag ${ }^{a}$ & Szórás & Min. ${ }^{b}$ & Max. ${ }^{c}$ \\
\hline Egyének száma a cellában (fő) & 7737 & 4590,50 & 6970,39 & 17,35 & 100848,70 \\
\hline születések száma (fő, első gyermek) & 7737 & 80,84 & 241,46 & 0,00 & 4330,00 \\
\hline $\begin{array}{l}\text { születések száma (fő, második gyermek) } \\
\text { születések száma (fő, harmadik és további }\end{array}$ & 7737 & 58,31 & 140,19 & 0,00 & 3042,00 \\
\hline gyermekek) & 7737 & 38,44 & 74,65 & 0,00 & 1144,00 \\
\hline eltartottsági arány (teljes) & 7737 & 0,58 & 0,04 & 0,50 & 0,68 \\
\hline eltartottsági arány (gyermek) & 7737 & 0,24 & 0,03 & 0,19 & 0,35 \\
\hline $\begin{array}{l}\text { eltartottsági arány (öregségi) } \\
\text { bölcsődei lefedettség (bölcsődei férőhelyek }\end{array}$ & 7737 & 0,34 & 0,04 & 0,24 & 0,46 \\
\hline $\begin{array}{l}\text { száma / 0-2 éves korú gyermekek száma) } \\
\text { óvodai ellátottság (óvodai férőhelyek száma }\end{array}$ & 7737 & 0,10 & 0,08 & 0,00 & 0,29 \\
\hline / 3-5 éves korú gyermekek száma) & 7214 & 1,13 & 0,09 & 0,90 & 1,36 \\
\hline egy főre eső SZJA (ezer Ft / év) & 7737 & 602,10 & 216,92 & 151,92 & 1197,50 \\
\hline regionális munkanélküliségi ráta (\%) & 7737 & 8 & 4 & 2 & 21 \\
\hline bruttó bér (nő) (Ft / hó) & 7737 & 51730,54 & 62146,90 & 0,00 & 276641,40 \\
\hline bruttó bér (partner) (Ft / hó) & 7737 & 102846,10 & 49018,66 & 0,00 & 376036,50 \\
\hline bruttó bér (család) (Ft / hó) & 7737 & 154576,70 & 92582,73 & 0,00 & 552202,80 \\
\hline partner foglalkoztatási aránya & 7695 & 0,83 & 0,19 & 0,00 & 1,00 \\
\hline tavaly költözött & 7737 & 0,01 & 0,05 & 0,00 & 1,00 \\
\hline részmunkaidős állások aránya & 6444 & 0,10 & 0,18 & 0,00 & 1,00 \\
\hline éjszakai műszakban dolgozók aránya & 6444 & 0,33 & 0,29 & 0,00 & 2,67 \\
\hline részmunkaidős állások aránya (partner) & 7593 & 0,04 & 0,08 & 0,00 & 1,00 \\
\hline második munkahely aránya (nő) & 6444 & 0,01 & 0,04 & 0,00 & 1,00 \\
\hline második munkahely aránya (partner) & 7593 & 0,02 & 0,05 & 0,00 & 1,00 \\
\hline $\begin{array}{l}\text { éjszakai műszakban dolgozók aránya } \\
\text { (partner) }\end{array}$ & 7593 & 0,54 & 0,28 & 0,00 & 2,80 \\
\hline $\begin{array}{l}\text { házasságok aránya } \\
\text { házas vagy élettársi kapcsolatban élők }\end{array}$ & 7737 & 0,64 & 0,25 & 0,00 & 1,00 \\
\hline aránya & 7737 & 0,87 & 0,12 & 0,00 & 1,00 \\
\hline női foglalkoztatási arány & 7737 & 0,54 & 0,24 & 0,00 & 1,00 \\
\hline női munkanélküliségi ráta & 7365 & 0,14 & 0,15 & 0,00 & 1,00 \\
\hline $\begin{array}{l}\text { gyermekek száma a háztartásokban } \\
\text { (maximum 3) (fő) }\end{array}$ & 7737 & 0,45 & 0,52 & 0,00 & 3,00 \\
\hline
\end{tabular}

Forrás: az elemzéshez összeállított adatbázis.

a A cellaátlagok átlaga.

b A legkisebb értékủ cellaátlag.

c A legnagyobb értékü cellaátlag. 


\section{ELEMZÉSI MÓDSZER}

A családpolitikai intézkedéseknek a termékenységre gyakorolt oksági hatásait vizsgáló ökonometriai elemzést az összevont adatbázison végezzük el. A becslési módszertan a már bemutatott elméleti modellen alapul. Panel fixhatás modellt számolunk, amely megye fix hatásokat tartalmaz az időben nem változó, helyspecifikus termékenységi különbségek kiszűrésére, valamint év fixhatásokat a makrogazdasági környezet azon elemeinek időbeli alakulásának kontrollálására, amelyek minden településen hasonlóan hatnak a TÉA-ra. Ez azt jelenti, hogy képesek vagyunk olyan nem megfigyelt tényezők hatását is kiszűrni, mint például az iparszerkezet, az etnikai összetétel vagy a helyi kulturális sajátosságok regionális különbségei, valamint a termékenységi ráták kezdeti különbségei.

Az 1. modellben a lineáris valószínüségi regresszió a következő formát ölti:

$$
\operatorname{Pr}\left(B_{c, t}^{g}=1\right)=\mu_{t-1}+\theta_{r}+\sum_{i=1}^{3} \beta^{\prime} X_{c, t-\mathrm{i}}+\sum_{i=1}^{3} \delta^{\prime} N C B_{c, t-\mathrm{i}}^{g}+\sum_{i=1}^{3} \gamma^{\prime}\left\{C B_{c, t-\mathrm{i}}^{g}-C B_{c, t-\mathrm{i}}^{g-1}\right\}+\epsilon_{c, t}
$$

ahol $\operatorname{Pr}\left(B_{c, t}^{g}=1\right)$ a $g$-edik gyermek megszületésének valószínüsége (ahol $g=\{1,2,3$ vagy több $\}$ ) a t-edik évben, a c-edik cellában, amelyet a termékenységi ráták cellaátlagával közelítünk. $g=0$, vagyis nulla gyermek esetén az elérhető készpénzes $\left(C B_{c}^{g}=0\right)$ és nem készpénzes $\left(N C B_{c}^{g}=0\right)$ családi juttatások összege nulla. A $\delta$ és $\gamma$ vektorok a becslés fő paraméterei, a nem pénzbeli ellátások $\left(N C B^{g}\right)$ és a $g$-edik gyermek vállalása esetén elérhető pénzbeli ellátások $\left(C B^{g}\right)$ hatása. A támogatások értékét 1, 2 és 3 éves késleltetéssel is szerepeltetjük. Mivel ebben a modellben az első, második vagy magasabb rendủ születések valószínűségét becsüljük, a pénzbeli előnyök (CB) a rendelkezésre álló többletforrások formájában szerepelnek, ha a jelenlegi gyermekszám 1-gyel nő, ami a $\left\{C B_{c, t-1}^{g}-C B_{c, t-1}^{g-1}\right\}$ mátrixban szerepel. $\mu_{\mathrm{t}}$ jelöli az év fixhatásokat, $\theta_{\mathrm{r}}$ pedig a megye fixhatásokat. $X_{c t}$ mátrix tartalmazza azon releváns mikro- és makroszintü kontrollváltozók cella szintủ átlagos értékét, amelyek befolyásolhatják a termékenységi döntéseket, például az anyák életkora, képzettsége, foglalkoztatottsága, az időskori eltartottak aránya ${ }^{3}$ (Id pl. Harknett, Billari and Medalia, 2014), a településtípus, az egy főre eső SZJA vagy a részmunkaidőben, éjszakai műszakban és másodállásban dolgozó nők aránya. A modellben 1, 2 és 3 éves hatásokat vizsgálunk. A regressziókban a cellák megfigyelés számát súlyként használjuk.

\footnotetext{
${ }^{3}$ Az időskori eltartottak elméletben csökkenthetik a gyermekvállalás költségeit, például azzal, ha a nagyszülők vigyáznak a gyermekekre. Ugyanakkor elképzelhető ellenkező irányú hatás is abban az esetben, ha a gondozásra szoruló időskori eltartottak csökkentik a gyermeknevelésre fordítható erőforrások mennyiségét.
} 
A 2. modellben a TÉA-ra gyakorolt hatást külön-külön támogatási formánként becsüljük:

$$
\begin{aligned}
\operatorname{Pr}\left(B_{c, t}=1\right)= & \mu_{t-1}+\theta_{r}+\sum_{i=1}^{3} \beta^{\prime} X_{c, t-\mathrm{i}}+\sum_{i=1}^{3} \sum_{k} \delta_{k^{\prime}} \frac{1}{3} \sum_{g=1}^{3} N C B_{c, t-\mathrm{i}}^{g, k} \\
& +\sum_{i=1}^{3} \sum_{j} \gamma_{j}{ }^{\prime} \frac{1}{3} \sum_{g=1}^{3}\left\{C B_{c, t-\mathrm{i}}^{g, j}-C B_{c, t-\mathrm{i}}^{g-1, j}\right\}+\epsilon_{c, t}
\end{aligned}
$$

ahol a függő változó a TÉA (első, második stb. gyermek esetében), és a szakpolitikai intézkedések a különböző gyermekszámokra átlagolva szerepelnek. A modell fő paraméterei $\delta_{k}$ és $\gamma$, amelyek a k-adik számú természetbeni, illetve a j-edik számú készpénzes támogatás TÉA-ra gyakorolt hatását mutatják.

\section{EREDMÉNYEK}

\section{A CSALÁDPOLITIKA ELEMEINEK ÖSSZESÍTETT HATÁSA}

Az 1. számú modell eredményeit a 4. táblázat tartalmazza. A várakozásoknak megfelelően az elsőszülöttek születését a későbbi születésekhez képest egészen más tényezők határozzák meg. Az első gyermekek esetében a termékenységi döntéseket leginkább a munkaerő-piaci lehetőségek befolyásolják, például a foglalkoztatási státusz, amely fontos a csecsemőgondozási díjra (TGYAS/CSED) és a gyermekgondozási dijra (GYED) való jogosultság szempontjából. Az eredmények arra utalnak, hogy a nők késleltetik az első szülést (vagyis az egy évvel későbbi termékenység (1-3. oszlop) csökken, majd a két évvel későbbi termékenység (4-6. oszlop) hasonló mértékben növekszik) abban az esetben, ha az elérhető családi ellátások növekednek. Azt is láthatjuk az adatokból, hogy a nők foglalkoztatottsága az első és a második évben is növeli a gyermekvállalás valószínüségét. Az első gyermekre vonatkozó negatív hatások valószínủleg a gyermekvállalás késleltetésének köszönhetőek. Ezeket az eredményeket leginkább a CSED és a GYED hatásai határozzák meg, amelyek erősen korrelálnak a bérekkel (ehhez még Id. az 5. táblázatot). A harmadik gyermek születése esetén a családi pénzbeli juttatások pozitív hatást gyakorolnak, a foglalkoztatás pedig negatívan kapcsolódik a TÉA-hoz. A különböző szakpolitikák két évvel későbbi hatásait vizsgálva (4. táblázat 4-6. oszlopai) azt láthatjuk, hogy az első és második születés hatásai éppen ellentétesek az egy éves hatásokkal, három évvel a szakpolitikai változások után (az eredménye- 
ket itt nem közöljük) pedig a hatások teljesen eltűnnek. Ezek az eredmények arra utalnak, hogy az első és a második születés esetében pusztán időzítési hatásról van szó. A harmadik születés esetében a családi pénzbeli juttatások pozitív hatása tartósnak tünik, mivel azt nem ellensúlyozza a harmadik születés valószínüségének későbbi csökkenése. Általánosságban elmondható, hogy a második szülésre gyakorolt hatás az első és a harmadik szülésre gyakorolt hatás átlaga.

Az elemzésnek ebben a részében az összes olyan, családdal kapcsolatos szakpolitika hatását összesítettük, amely bármilyen hatással lehet a termékenységre. Azt találtuk, hogy a juttatási rendszer egésze a harmadik születések számának növelése révén enyhe pozitív hatást gyakorol a termékenységre. Ezek többnyire összhangban vannak a szakirodalom korábbi eredményeivel, amelyek a családpolitikák kismértékű pozitív hatását állapítják meg. Amint azt a következő szakaszban bemutatjuk, ez a kombinált hatás a családpolitikai rendszer különböző részeinek jelentős pozitív hatásaiból és zérus hatásaiból tevődik össze.

A bölcsődék lefedettségének hatása az első évben nulla, míg a második évben pozitív. A bölcsődei férőhelyek elérhetősége az elsőszülöttek esetében nagyobb jelentőséggel bír, és ez a hatás a későbbi születéseknél csökken. Mindez összhangban van azzal a megfigyeléssel, hogy az első gyermekes anyák jobban kötődnek a munkaerőpiachoz, termékenységüket leginkább a foglalkoztatás befolyásolja, emellett valószínűleg őket foglalkoztatja leginkább a szülés utáni munkaerő-piaci visszatérés gondolata. A harmadik gyermeket szülőket viszont kevésbé érintik ezek a kérdések, ugyanis sokkal lazábban kötődnek a munkaerőpiachoz, így valószínűleg kevésbé befolyásolja őket a bölcsődei lefedettség.

Az eredmények azt sugallják, hogy az a gyermekre törvényileg meghatározott minimális életkor, amikortól a nők részmunkaidőben dolgozhatnak anélkül, hogy elveszítenék a pénzbeli juttatásokat, jelentősen növelné a termékenységet, ami ellentmondásosnak tűnik. Ebben a modellben a családi ellátásokra vonatkozó szabályok stabilitásának nincs jelentős hatása.

A többi változó becsült együtthatói statisztikailag szignifikánsak és a várt irányba mutatnak. Míg a magasabb iskolai végzettségü nők kisebb valószínüséggel szülnek többedik gyermeket, addig az első szülések a fiatalabb korosztályokban fordulnak elő. A részmunkaidőben dolgozó nők között nagyobb az elsőszülések valószínűsége, de az éjszakai műszak és a másodállás csökkenti a harmadik szülések valószínüségét. 
4. tábla: Regressziós eredmények: 1. modell

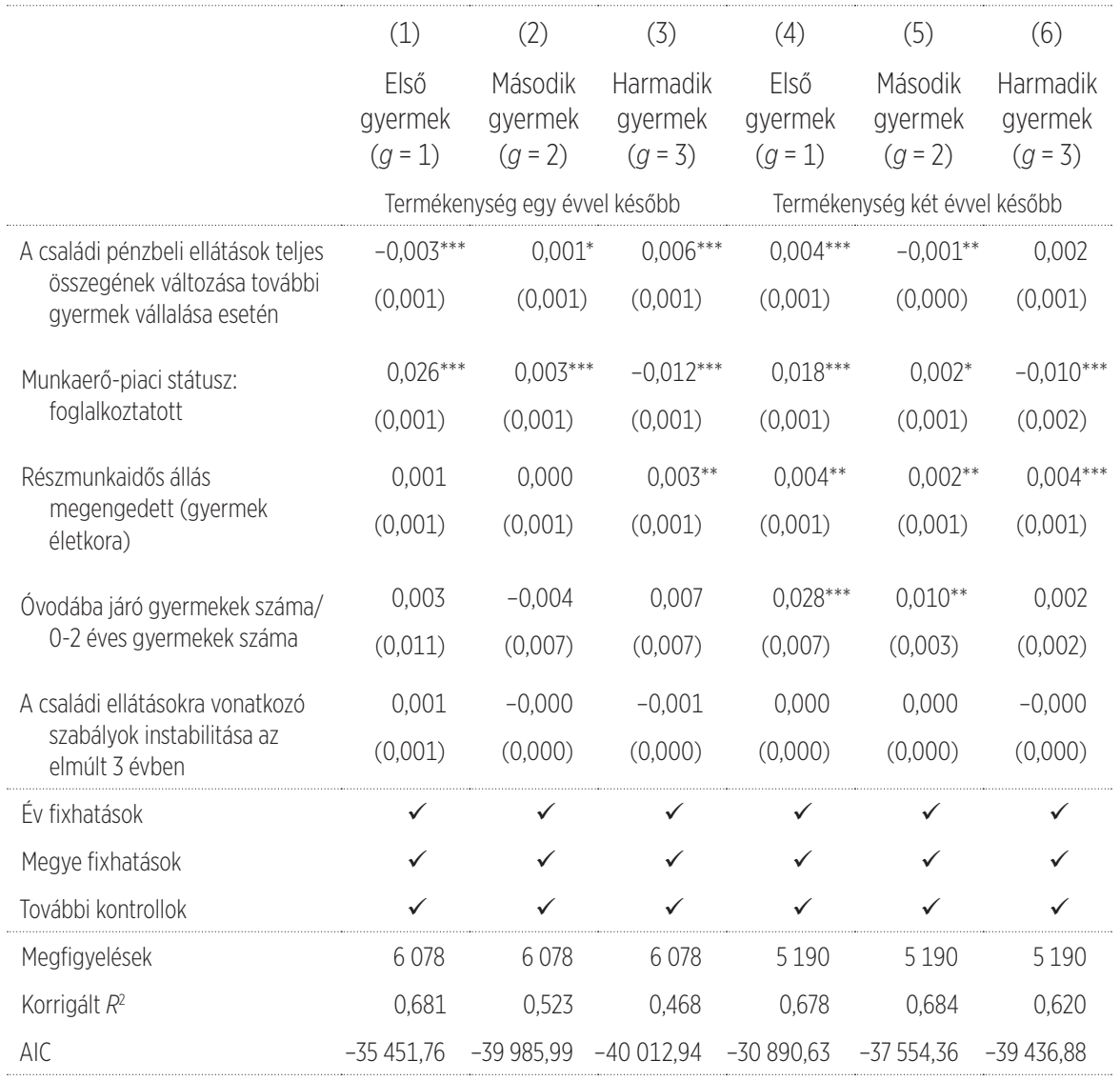

Megjegyzés: Huber-White féle robusztus standard hibák zárójelben. A szignifikancia jelzése: ${ }^{*} p<0,05,{ }^{* *} p<0,01$, ${ }^{* * *} p<0,001$.

\section{A CSALÁDPOLITIKA ELEMEINEK EGYEDI HATÁSA}

Amint azt az 5. táblázat B paneljében közöljük, a bölcsődei lefedettség nagymértékű pozitív hatást gyakorol a TÉA-ra . Az első év hatását egy nem szignifikáns második év és egy gyengén szignifikáns harmadik év pozitív hatása egészíti ki.

\footnotetext{
${ }^{4}$ Ahol lehetséges, ott az 5. táblázat B paneljében közölt, év fixhatásokat tartalmazó modell együtthatóit használjuk, míg más esetekben az 5. táblázat A paneljében szereplő, év fixhatások nélküli modell eredményeit alkalmazzuk.
} 
A jelentős hatásokat összeadva a lefedettség 1 százalékpontos növekedése 0,046 százalékponttal növelné a TÉA-t, ami a következő évben a TÉA 1,18\%-os növekedését jelentené (az évi 3,87\%-os átlagos TÉA-hoz képest), ami évente átlagosan körülbelül 973 születést jelent. Összehasonlításképpen: 2000 és 2014 között a bölcsődei lefedettség 7,8\%-ról 13,1\%-ra (5,3 százalékponttal) nőtt. Nagyságrendileg ehhez fogható a 2019-ben bejelentett bölcsődei férőhelybővitési program, ami a rendelkezésre álló férőhelyek számát 49 ezerről mintegy 70 ezerre tervezte bővíteni.

A családi adókedvezmény ennél hosszabb távon befolyásolja a TÉA-t. Az első két évben egyáltalán nincs rá hatása, azonban a harmadik évben növeli azt. A rendelkezésre álló családi adókedvezmény 10\%-kal (mintegy 30 milliárd forinttal) való növelése a szülési TÉA-t növelné 0,103 százalékponttal (2,5\%, kb. 2375 születés). Ez a hatás nagyon hasonló Gábos et al. (2009) eredményéhez, akik arról számolnak be, hogy „a gyermekvállaláshoz kapcsolódó juttatások 1\%-os növelése 0,2\%-kal növelné az összes termékenységet, ahol a gyermekvállaláshoz kapcsolódó juttatások közé tartozik a családi pótlék, az adókedvezmény, az anyasági támogatás és a gyermekgondozási díj, a gyermekgondozási segély, az anyasági támogatás és a gyermeknevelési támogatás."

A CSED és a GYED kombinált mérőszáma az első évben szignifikáns negatív hatást mutat, a harmadik évben pedig közel azonos mértékủ szignifikáns pozitív hatást, ami a támogatások puszta késleltetési hatását jelzi. A lakáshitel kamattámogatásának hatása enyhén szignifikáns, de összességében elhanyagolható. A többi családi kedvezményt kihagytuk a modellből, hiszen az átlagos összeg éves szinten változik, így ezek teljes mértékben korrelálnak az év fixhatásokkal.

Az A panel az otthonteremtési támogatás jelentős pozitív hatását jelzi a harmadik évben. A paraméterbecslés azt mutatja, hogy a támogatás 1 százalékpontos növekedése 0,047 százalékpontos növekedést (1,2\% a 3,87\%-os kiindulási TÉA-hoz képest, ami évi 1099 további születésnek felel meg) eredményez a TÉA-ban. 
5. tábla: Regressziós eredmények - 2. modell

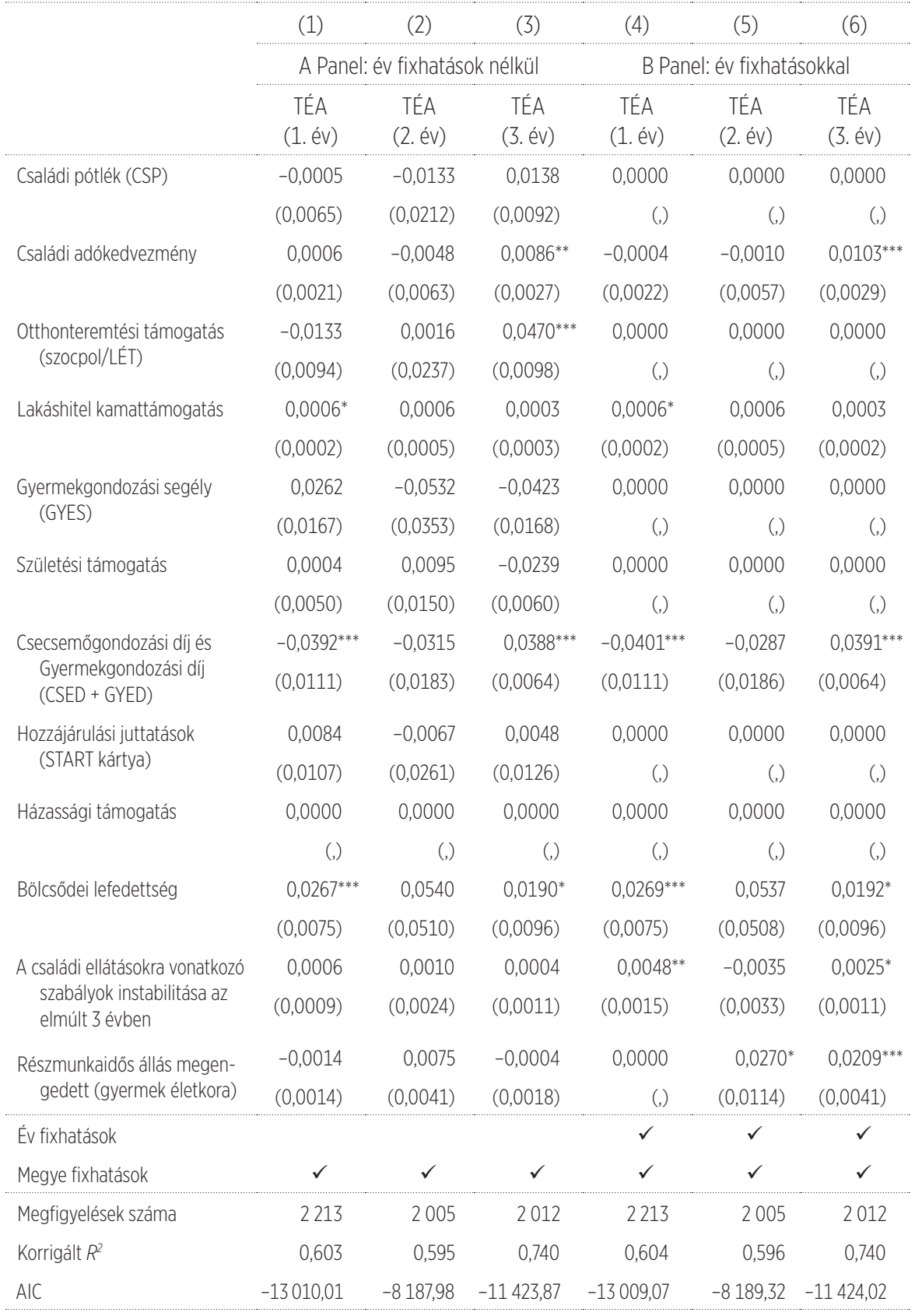

Megjegyzés: Standard hibák zárójelben. Szignifikancia: ${ }^{*} p<0,05,{ }^{* *} p<0,01,{ }^{* * *} p<0,001$. 
Az 5. táblázat B paneljében az eredeti specifikációval végzett regressziós eredmények láthatóak. A regressziókban év fixhatások szerepelnek, így az összes nem bérfüggő támogatás kiesik multikollinearitás miatt, mivel a kapott juttatás összege pontosan a kétértékű év (dummy) változókkal együtt változik. Ez a becsülhető együtthatókat nem torzítja, csupán annyi történik, hogy az év fixhatások együtthatói felveszik a kieső támogatások hatását is. Annak érdekében, hogy feltárjuk e szakpolitikák hatását az A panelben olyan regressziós eredményeket mutatunk be, amelyek pontosan ugyanabból a specifikációból származnak, kivéve az év fixhatásokat. Az A és a B panel megfelelő oszlopainak összehasonlítása azt mutatja, hogy az év fixhatások figyelembevétele fontos (lásd például a családi adókedvezmény együtthatóját), de a két specifikációból becsült együtthatók ugyanabba az irányba mutatnak. Ennek eredményeképpen a B panelben közölt, bérfüggő juttatások paraméterbecsléseit használjuk (mindazokat, amelyek nem estek ki az általunk preferált modellből), a többit pedig az A panelből.

A mérésekhez felhasznált adatok és az előállított szakpolitikai mérőszámok legnagyobb limitációja azok aggregáltsága. Mivel a méréshez szükséges információk nem állnak rendelkezése egyetlen adatbázisban sem, ezért kénytelenek vagyunk speciálisan aggregálni és összekötni a különféle adatbázisok adatait. Ezzel olyan mérési hibát vittünk be az elemzésbe, amely a nulla irányában torzíthatta becsléseinket.

\section{ÖSSZEGZÉS}

Cikkünkben aggregált adatbázis segítségével becsüljük meg a hazai családtámogatási politika hatását a tisztított élveszületési arányszámra. Becsléseinkhez a KSH Élveszületési Adatbázis, a KSH Demográfiai Évkönyv, a KSH Munkaerőfelmérés és az ÁFSZ Bértarifa felvétel adatait használtuk fel. A fixhatás panel modellek a családpolitikák együttes és különálló hatásait mérik.

Modellünk eredményei azt mutatják, hogy a családtámogatási rendszer öszszességében vett hatása alacsony. Ez valószínűleg abból fakad, hogy a teljes egészében figyelembe vett támogatási rendszernek vannak a születésszám növelése szempontjából hatékonyabb és kevésbé hatékony elemei. Az egyetlen szignifikáns hatás, amelyet találtunk az a harmadik születés valószínűségének növekedése. A rendszer egyes elemei azonban jelentős termékenységi hatást gyakorolnak. Azt találtuk, hogy a gyermekvállalás utáni újbóli elhelyezkedés valószínűségével kapcsolatos tényezők, azaz a nők jelenlegi foglalkoztatottsága, 
a bölcsőde, óvoda elérhetősége és a részmunkaidős munkalehetőségek jelentősen növelik a TÉA-t. Ez különösen igaz az első gyermek vállalása esetében. Ennek azért van nagy jelentősége, mert az elmúlt években megnőtt a gyermeket nem vállalók aránya a magyar társadalomban (Spéder, 2021). Emellett a családi adókedvezmény révén a rendelkezésre álló jövedelem növekedése, valamint az otthonteremtési támogatás által elérhetőbbé váló lakhatás pozitív hatással van a termékenységre. Összességében a hazai beavatkozások hasonló eredményességet mutatnak, mint a többi országban folytatott hasonló szakpolitikák: enyhén pozitív, szignifikáns hatással vannak a termékenységre.

A korábbi szakirodalom rendszerint azt találja, hogy a termékenységi döntéseket elsősorban a foglalkoztatás, a megélhetés és a lakhatási kilátások befolyásolják. Eredményeink egyértelműen azt mutatják, hogy a családi ellátórendszer azon elemei bírnak a legjelentősebb termékenységi hatással, amelyek ezeket a területeket célozzák.

Ennek a megállapításnak két fontos következménye van, amelyek segithetnek a politikai döntéshozóknak a nemzeti termékenységi politikai rendszer hatékonyságának növelésében. Először is, a foglalkoztatás és a bérek növelését célzó gazdaságpolitikák valószínúleg még akkor is a leghatékonyabb termékenységi politikák közé tartoznak, ha általában nem tekintjük ezeket a családtámogatási rendszer részének. Másodszor, az eredmények rámutatnak arra, hogy a megfizethető lakhatás kulcsfontosságú tényező a gyermekvállalási döntésekben. Rindfuss és Brauner-Otto (2008) 1 azt állítják, hogy ez a cél a könnyen és olcsón elérhető jelzáloghitelekkel (amelyeket a jelenlegi rendszer támogat) és a megfizethető bérlakásokkal érhető el, ami rávilágít arra, hogy a lakásbérleti piac fejlesztése és az állam által biztosított bérlakások a termékenységet támogató stratégia létfontosságú részét képezhetik. 


\section{IRODALOM}

Aassve, A., Billari, F. C., and Spéder, Zs. (2006). Societal Transition, Policy Changes and Family Formation: Evidence from Hungary. European Journal of Population / Revue Européenne de Démographie, 22(2), 127-152.

Ang, X. L. (2015). The Effects of Cash Transfer Fertility Incentives and Parental Leave Benefits on Fertility and Labor Supply: Evidence from Two Natural Experiments. Journal of Family and Economic Issues, 36(2), 263-288. https://doi.org/10.1007/s10834014-9394-3

Becker, G. (1960). An Economic Analysis of Fertility. [NBER Chapters]. National Bureau of Economic Research, Inc. National Bureau of Economic Research, Inc., 209-240. website: https://econpapers.repec.org/bookchap/nbrnberch/2387.htm

Das, S. (2019). Essays in Development Economics with Special Emphasis on Gender Inequalities. PhD Dissertation, Central European University Department of Economics and Business.

Ermisch, J. (1988). Econometric Analysis of Birth Rate Dynamics in Britain. The Journal of Human Resources, 23(4), 563-576. JSTOR. https://doi.org/10.2307/145814

Gábos A., Gál R. I. és Kézdi G. (2009). The effects of child-related benefits and pensions on fertility by birth order: A test on Hungarian data. Population Studies, 63(3), 215-231. https://doi.org/10.1080/00324720903215293

Greulich, A., Thevenon, O. and Guergoat-Lariviere, M. (2015). Securing women's employment: A fertility booster in European countries? <hal-01298946>.

Harknett, K., Billari, F. C. and Medalia, C. (2014). Do Family Support Environments Influence Fertility? Evidence from 20 European Countries. European Journal of Population, 30(1), 1-33. https://doi.org/10.1007/s10680-013-9308-3

Kapitány B. és Spéder Zs. (2007). Vágyak és tények. Dinamikus termékenységi elemzések. KSH Népességtudományi Kutatóintézet, Műhelytanulmányok. Elérés forrás http:// demografia.hu/kiadvanyokonline/index.php/muhelytanulmanyok/issue/view/324

Laroque, G. and Salanié, B. (2008). Does Fertility Respond to Financial Incentives? (Sz. 3575). Institute for the Study of Labor (IZA). Elérés forrás Institute for the Study of Labor (IZA) website: https://ideas.repec.org/p/iza/izadps/dp3575.html

Monostori J., Őri P. és Spéder Zs. (2018). Demográfiai Portré 2018. Jelentés a magyar népesség helyzetéről. KSH Népességtudományi Kutatóintézet. Elérés forrás http://demografia.hu/kiadvanyokonline/index.php/demografiaiportre/article/ view/2741/2629

Rindfuss, R. R. and Brauner-Otto, S. R. (2008). Institutions and the transition to adulthood: Implications for fertility tempo in low-fertility settings. Vienna Yearbook of Population Research, 2008, 57-87. https://doi.org/10.1553/populationyearbook2008s57

Spéder Zs. (2021). Termékenységi mintaváltás - a családalapítás átalakulásának demográfiai nyomvonalai Magyarországon. Szociológiai Szemle, 31(2), 4-29. https://doi.org/HTTPS://DOI.ORG/10.51624/SZOCSZEMLE.2021.2.1

Zhang, J., Quan, J. and van Meerbergen, P. (1994). The Effect of Tax-Transfer Policies on Fertility in Canada, 1921-88. The Journal of Human Resources, 29(1), 181-201. JSTOR. https://doi.org/10.2307/146061 


\section{MELLÉKLET}

\section{1. melléklet: A bérbecslés módszere}

Az ÁFSZ Bértarifa felvétel adatait felhasználva minden [év - nem - várostípus - megye - iskolai végzettség - foglalkozás - életkor] cellára vonatkozóan kiszámítjuk a megfelelően súlyozott átlagbért és azt imputált bérként használjuk a munkaerő-felmérés adataiban. A MEF adatbázisban 962836 olyan megfigyelés volt, amelyhez pontos cellaátlagot tudtunk rendelni, illetve 88359 olyan, amelyhez nem tudtunk. Ennek az az oka, hogy vannak olyan cellák, amelyekben az adott időszakban nincs megfigyelés a mintában. A hiányzó béradatok pótlására a következő bérregressziót használjuk:

$$
\begin{aligned}
& \log (\text { BruttóBér })_{i}
\end{aligned}
$$

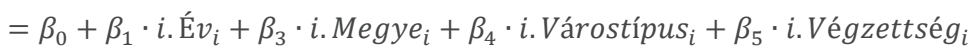

$$
\begin{aligned}
& +\beta_{6} \cdot i \text {. Életkor } i+\beta_{7} \cdot \text { Fehérgalléros }_{i}+\epsilon_{1}
\end{aligned}
$$

Az így kapott regressziós eredményeket az A.1 táblázat tartalmazza. A becsült együtthatók segítségével minden egyes cellára illesztett értékeket számolunk, és ezeket az illesztett értékeket használjuk minden (illesztett és nem illesztett) cellára az elemzés további részében. A béregyenlet R-négyzet értéke 80\% feletti, így a prediktált bérek jól illeszkednek az eredeti béradatokhoz. 


\section{A.l tábla: Bérregressziós eredmények}

(2)

(1)

Férfi

\begin{tabular}{|c|c|c|}
\hline & Nő & Férfi \\
\hline \multirow[t]{2}{*}{2000} & 0.000 & 0.000 \\
\hline & (.) & (.) \\
\hline \multirow[t]{2}{*}{2001} & $0.165^{* * *}$ & $0.153^{* * *}$ \\
\hline & $(0.001)$ & $(0.001)$ \\
\hline \multirow[t]{2}{*}{2002} & $0.329^{* * *}$ & $0.248^{* * *}$ \\
\hline & $(0.001)$ & $(0.001)$ \\
\hline \multirow[t]{2}{*}{2003} & $0.444^{* * *}$ & $0.320^{* * *}$ \\
\hline & $(0.001)$ & $(0.001)$ \\
\hline \multirow[t]{2}{*}{2004} & $0.482^{* * *}$ & $0.393^{* * *}$ \\
\hline & $(0.001)$ & $(0.001)$ \\
\hline \multirow[t]{2}{*}{2005} & $0.561^{* * *}$ & $0.457^{* * *}$ \\
\hline & $(0.001)$ & $(0.001)$ \\
\hline \multirow[t]{2}{*}{2006} & $0.628^{* * *}$ & $0.523^{* * *}$ \\
\hline & $(0.001)$ & $(0.002)$ \\
\hline \multirow[t]{2}{*}{2007} & $0.713^{* * *}$ & $0.651^{* * *}$ \\
\hline & $(0.001)$ & $(0.002)$ \\
\hline \multirow[t]{2}{*}{2008} & $0.776^{* * *}$ & $0.711^{* * *}$ \\
\hline & $(0.001)$ & $(0.002)$ \\
\hline \multirow[t]{2}{*}{2009} & $0.781^{* * *}$ & $0.683^{* * *}$ \\
\hline & $(0.001)$ & $(0.002)$ \\
\hline \multirow[t]{2}{*}{2010} & $0.799^{* * *}$ & $0.716^{* * *}$ \\
\hline & $(0.001)$ & $(0.002)$ \\
\hline \multirow[t]{2}{*}{2011} & $0.832^{* * *}$ & $0.762^{* * *}$ \\
\hline & $(0.001)$ & $(0.002)$ \\
\hline \multirow[t]{2}{*}{2012} & $0.953^{* * *}$ & $0.907^{* * *}$ \\
\hline & $(0.001)$ & $(0.002)$ \\
\hline \multirow[t]{2}{*}{2013} & $0.951^{* * *}$ & $0.874^{* * *}$ \\
\hline & $(0.001)$ & $(0.002)$ \\
\hline \multirow[t]{2}{*}{2014} & $1.002^{* * *}$ & $0.914^{* * *}$ \\
\hline & $(0.001)$ & $(0.002)$ \\
\hline \multirow[t]{2}{*}{2015} & $1.021^{* * *}$ & $0.937^{* * *}$ \\
\hline & $(0.001)$ & $(0.002)$ \\
\hline \multirow[t]{2}{*}{2016} & $1.066^{* * *}$ & $0.984^{* * *}$ \\
\hline & $(0.001)$ & $(0.002)$ \\
\hline
\end{tabular}

Megjegyzés: Standard hibák zárójelben. A szignifikancia jelzése: * $p<0.05,{ }^{* *} p<0.01,{ }^{* * *} p<0.001$

a Budapestnek külön megyekódja és külön településkódja is van, így a településkód=1 e kollinearitás miatt kimarad. A településkód=3 mint báziskategória kimarad a regresszióból. 


\section{A.l tábla: Bérregressziós eredmények (folytatás)}

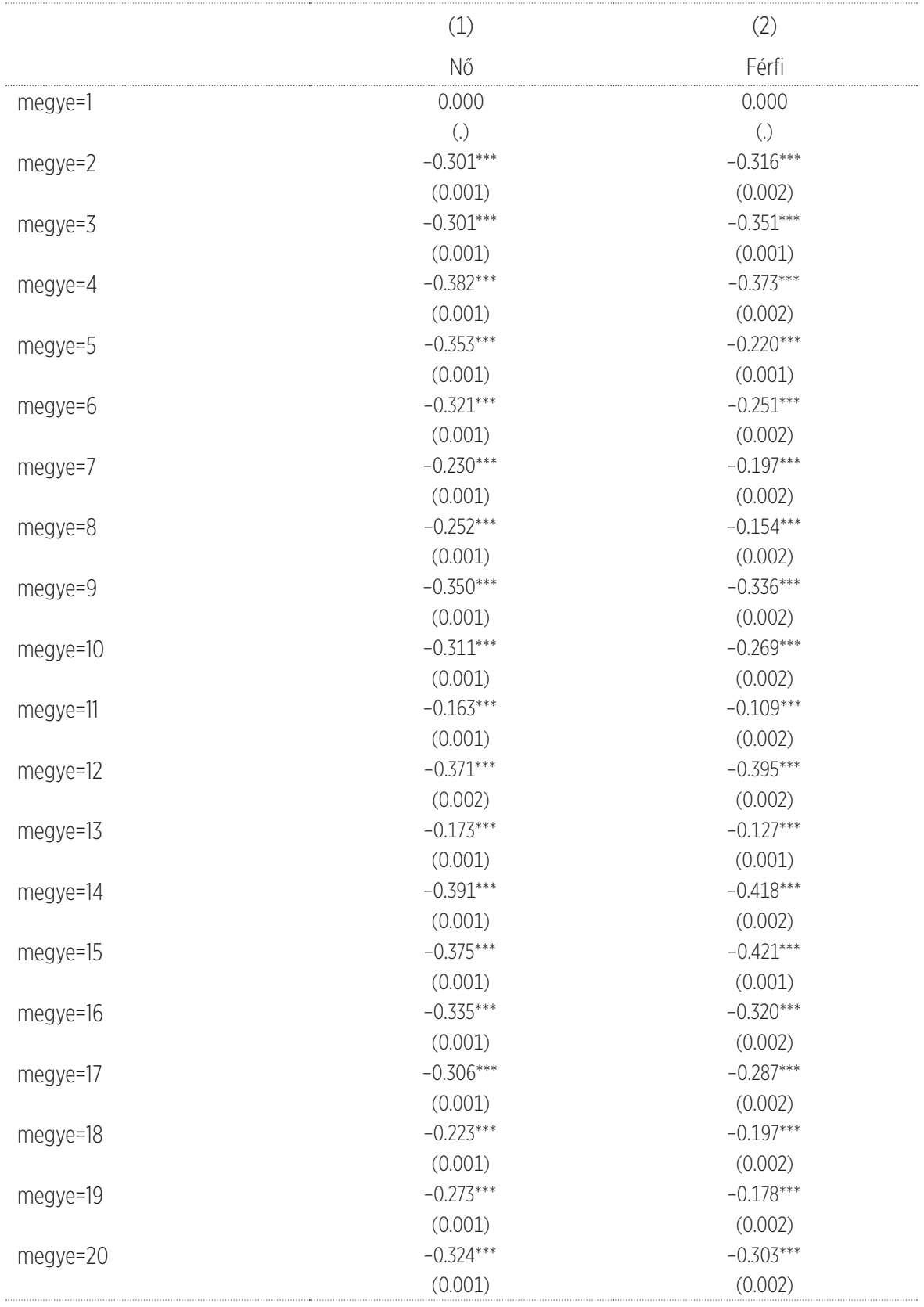

Megjegyzés: Standard hibák zárójelben. A szignifikancia jelzése: ${ }^{*} p<0.05,{ }^{* *} p<0.01,{ }^{* * *} p<0.001$

a Budapestnek külön megyekódja és külön településkódja is van, így a településkód=1 e kollinearitás miatt kimarad. A településkód=3 mint báziskategória kimarad a regresszióból. 


\section{A.l tábla: Bérregressziós eredmények (folytatás)}

\begin{tabular}{|c|c|c|}
\hline & (1) & $(2)$ \\
\hline & Nő & Férfi \\
\hline & $(0.001)$ & $(0.002)$ \\
\hline \multirow[t]{2}{*}{ településtípus=1a } & 0.000 & 0.000 \\
\hline & (.) & (.) \\
\hline \multirow[t]{2}{*}{ településtípus=2 } & $0.093^{* * *}$ & $0.110^{* * *}$ \\
\hline & $(0.000)$ & $(0.001)$ \\
\hline \multirow[t]{2}{*}{ településtípus=3 } & 0.000 & 0.000 \\
\hline & (.) & (.) \\
\hline \multirow[t]{2}{*}{ iskolai végzettség: magas } & $0.133^{* * *}$ & $0.208^{* * *}$ \\
\hline & $(0.001)$ & $(0.001)$ \\
\hline \multirow[t]{2}{*}{ korcsoport=15 } & 0.000 & 0.000 \\
\hline & (.) & (.) \\
\hline \multirow[t]{2}{*}{ korcsoport=20 } & $-0.011^{* * *}$ & $0.061^{* * *}$ \\
\hline & $(0.001)$ & $(0.001)$ \\
\hline \multirow[t]{2}{*}{ korcsoport=25 } & $0.060^{* * *}$ & $0.184^{* * *}$ \\
\hline & $(0.001)$ & $(0.001)$ \\
\hline \multirow[t]{2}{*}{ korcsoport=30 } & $0.104^{* * *}$ & $0.297^{* * *}$ \\
\hline & $(0.001)$ & $(0.001)$ \\
\hline \multirow[t]{2}{*}{ korcsoport=35 } & $0.131^{* * *}$ & $0.354^{* * *}$ \\
\hline & $(0.001)$ & $(0.001)$ \\
\hline \multirow[t]{2}{*}{ korcsoport=40 } & $0.154^{* * *}$ & $0.368^{* * *}$ \\
\hline & $(0.001)$ & $(0.001)$ \\
\hline \multirow[t]{2}{*}{ korcsoport=45 } & $0.170^{* * *}$ & $0.371^{* * *}$ \\
\hline & $(0.001)$ & $(0.001)$ \\
\hline \multirow[t]{2}{*}{ korcsoport=50 } & $0.176^{* * *}$ & $0.367^{* * *}$ \\
\hline & $(0.001)$ & $(0.001)$ \\
\hline \multirow[t]{2}{*}{ korcsoport=55 } & $0.158^{* * *}$ & $0.350^{* * *}$ \\
\hline & $(0.001)$ & $(0.001)$ \\
\hline \multirow[t]{2}{*}{ fehérgalléros } & $0.517^{* * *}$ & $0.529^{* * *}$ \\
\hline & $(0.001)$ & $(0.001)$ \\
\hline \multirow[t]{2}{*}{ Konstans } & $10.808^{* * *}$ & $10.921^{* * *}$ \\
\hline & $(0.001)$ & $(0.002)$ \\
\hline Megfigyelések & 540747 & 543344 \\
\hline Korrigált $\mathrm{R}^{2}$ & 0.890 & 0.844 \\
\hline AIC & -464702.787 & -207040.872 \\
\hline
\end{tabular}

Megjegyzés: Standard hibák zárójelben. A szignifikancia jelzése: ${ }^{*} p<0.05,{ }^{* *} p<0.01,{ }^{* * *} p<0.001$

a Budapestnek külön megyekódja és külön településkódja is van, így a településkód=1 e kollinearitás miatt kimarad. A településkód=3 mint báziskategória kimarad a regresszióból. 


\section{2. melléklet: Otthonteremtési támogatás}

Az alábbiakban röviden összefoglaljuk az otthonteremtési támogatás számítását.

1. Az átlagos lakásárak kiszámítása évenként, megyénként és településtípusonként:

a. Ehhez az ELTINGA Ingatlanpiaci Kutatóközpont és a KSH által szolgáltatott lakásáradatokat használjuk.

b. A 2008 előtti évekre a falusi lakásárakat a Magyar Nemzeti Bank falusi lakásárindexe alapján számítjuk ki.

2. A fő adatbázisunkban az adott cellákban (év - anya munkaerő-piaci státusza - megye - településtípus - 10 éves korcsoport - iskolai végzettség - gyermekszám) a családok átlagbére áll rendelkezésünkre.

3. A piaci kamatozású lakásvásárlási hitelek törlesztőrészletének kiszámításához a Magyar Nemzeti Bank által közzétett átlagos hitelköltséget használjuk. A következő feltételezésekre kellett támaszkodnunk:
a. 20 éves időtartam,
b. A lakásvásárlások 100\%-át bankhitelből finanszírozzák,
c. A vásárlók először az összes elérhető állami támogatást igénybe ve- szik és csak ezután folyamodnak piaci alapú hitelekhez.

4. A támogatott hitelek kamatlábának kiszámítása alapján:
a. a 12/2001, 134/2009 és 341/2011 kormányrendeletek,
b. az Államadósság Kezelő Központ által közzétett és a Magyar Nemzeti Bank honlapján elérhető államkötvények havi referenciahozamai,
c. részletek az A.2 táblázatban.

5. Akik számára elérhetőek a hiteltámogatások:
a. Ha a törlesztőrészlet meghaladja a család teljes bérének 30\%-át (az elérhető támogatások figyelembevétele után), akkor a család nem mi- nősül hitelképesnek, így nem juthat lakástámogatáshoz.
b. Az elég magas háztartási összbérrel rendelkező családok úgy tekint- hetők, hogy számukra elérhetőek a lakástulajdonlási támogatások.


6. A támogatás összege

a. Az eszközök következő sorrendjét feltételezzük:

i. Először a lakástulajdonlási támogatást a rendelkezésre álló összeg erejéig veszik igénybe

ii. Másodszor a kamattámogatást veszik igénybe

iii. Végül a piaci alapú hitel

iv. Összességében a ház értékéig.

b. A rendelkezésre álló kamattámogatás összegét a piaci kamatlábak mellett fizetett teljes kamat (mennyi lenne a piaci kamatláb teljes öszszege egy, a rendelkezésre álló támogatott hitelhez hasonló nagyságú hitel teljes futamideje alatt) és a támogatott kamatlábak mellett fizetett teljes kamat különbözeteként kell kiszámítani.

c. A Magyar Államkincstár adatai szerint a támogatott hitelszerződések az A.2 táblázatban feltüntetett években jöttek létre. 


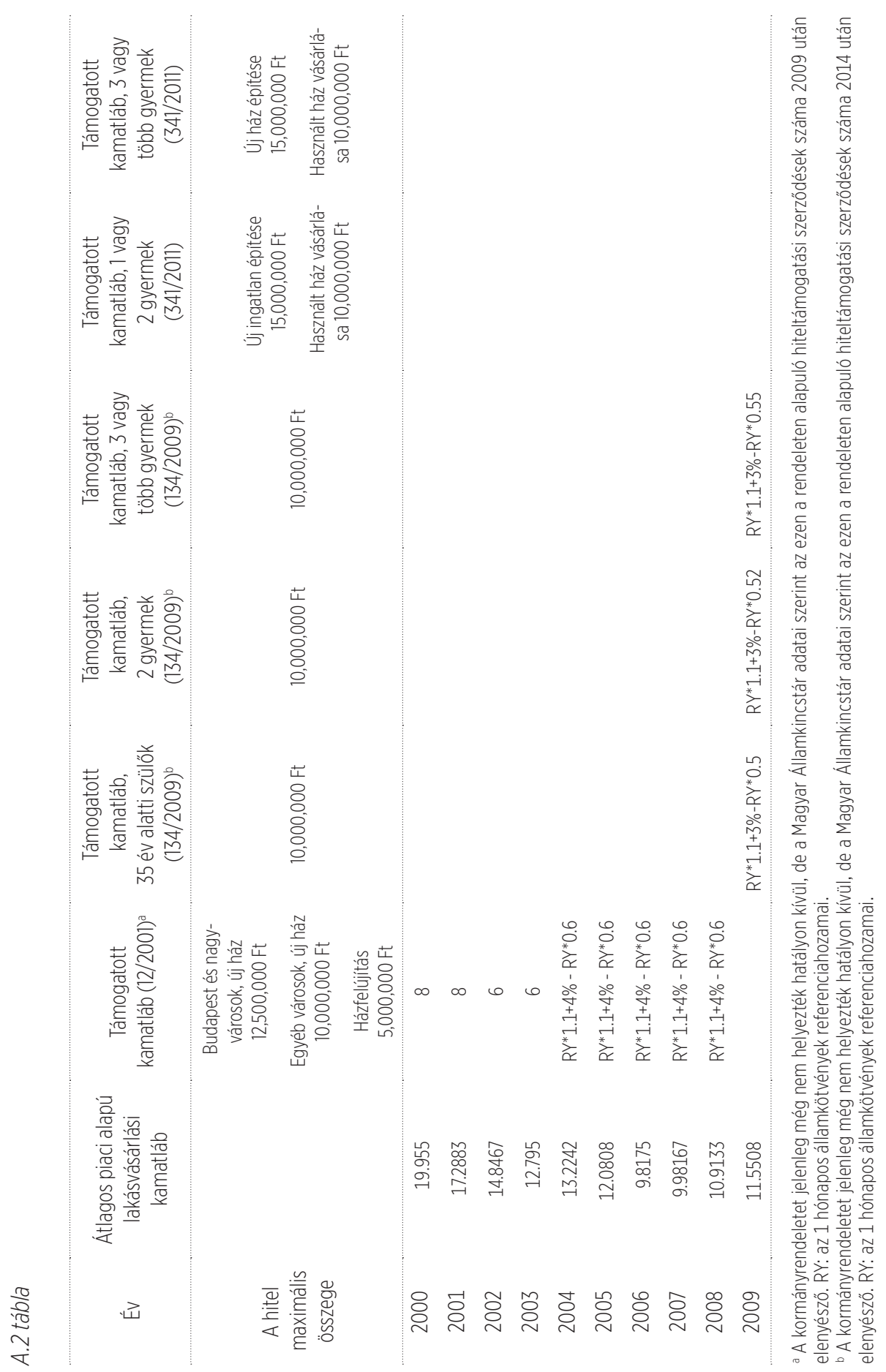




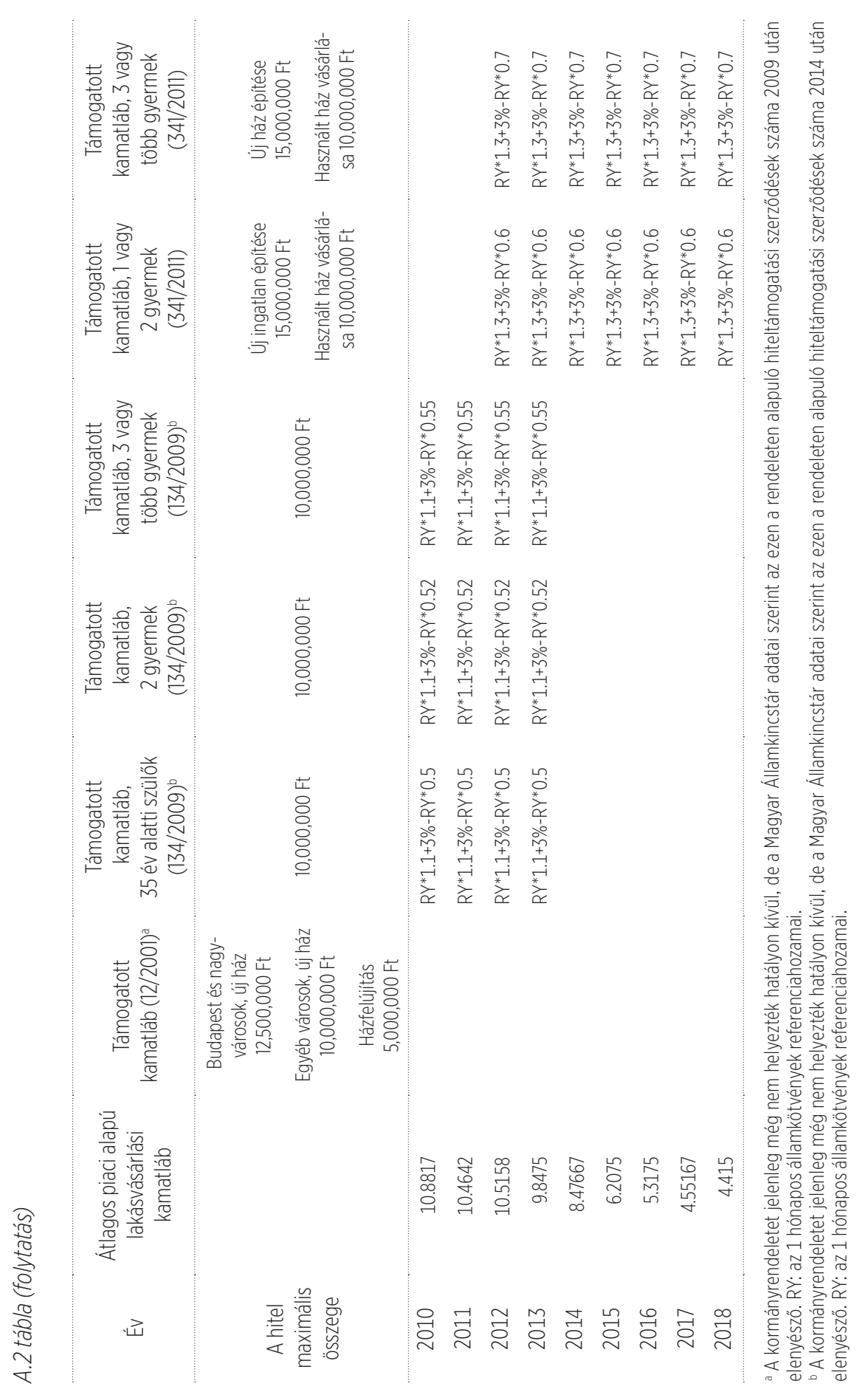




\section{3. számú melléklet: Pénzügyi intézkedések stabilitása az el- múlt 3 évben}

A kormányzati intézkedések stabilitásának mérőszáma a gyermektervezés politikai környezetének bizonytalanságát méri. Az A.3 táblázat bemutatja, hogy mit tekintünk változásnak és mit nem. Az A.4 táblázat az egyes években eseménynek tekintett pontos változásokat mutatja. A becslésekhez az elmúlt 3 év változásainak számát az elmúlt 3 év súlyozott átlagaként számoljuk ki (beleértve az aktuális évet is). 100\%-os súlyt kap az aktuális, 60\%-ot a tavalyi és 30\%-ot az azt megelőző év. Ezáltal figyelembe vesszük azt a tényt, hogy az emberek idővel hozzászoknak a változásokhoz.

\section{A.3 tábla}

Változásnak számít

Jelentős változás a jogosultságban

pl. otthonteremtési támogatás

Jelentős változás az időtartamban

Jelentős változás az összegben

pl. a családi pótlék 2006-ban kb. 100\%-kal emelkedik.

Jelentős változás még akkor is, pl. 2 gyermekes családok otthonteremtési ha nem minden jogosult csoportot érint. támogatása

Nem számít változásnak

Jelentéktelen változás a juttatásban

pl. a TGYÁS megszünt, és bevezették a CSED-et, de alapvetően hasonló összeggel és szabályokkal

Kevesebb, mint $50 \%$-os változás az összegben

pl. GYES 


\section{A.4 tábla}

\begin{tabular}{|c|c|c|c|}
\hline Év & $\begin{array}{l}\text { A változások } \\
\text { száma az adott } \\
\text { évben }\end{array}$ & $\begin{array}{l}\text { A változások } \\
\text { száma az elmúlt } \\
3 \text { évben }\end{array}$ & Részletek \\
\hline \multicolumn{4}{|l|}{2000} \\
\hline 2001 & 1 & a & 1.) Új otthonteremtési támogatási rendelet \\
\hline 2002 & & 0.6 & \\
\hline 2003 & & 0.3 & \\
\hline 2004 & & 0 & \\
\hline 2005 & & 0 & \\
\hline \multirow{3}{*}{2006} & \multirow{3}{*}{3} & \multirow{3}{*}{3} & 1.) A családi pótlék megduplázódik \\
\hline & & & $\begin{array}{l}\text { 2.) GYES: teljes munkaidős foglalkoztatás a gyermek } 1 \\
\text { éves korától, részmunkaidős foglalkoztatás 0,5 éves } \\
\text { kortól engedélyezett }\end{array}$ \\
\hline & & & $\begin{array}{l}\text { 3.) A családi adókedvezmény rendszer szabályainak } \\
\text { változása }\end{array}$ \\
\hline 2007 & & 1.8 & \\
\hline 2008 & & 0.9 & \\
\hline 2009 & 1 & 1 & 1.) Új otthonteremtési támogatási rendelet \\
\hline \multirow{4}{*}{2010} & \multirow{4}{*}{4} & \multirow{4}{*}{4.6} & 1.) A családi pótlék időtartama 23-ról 20 évre csökken \\
\hline & & & 2.) A GYED-et érintő társadalombiztosítási rendelet \\
\hline & & & $\begin{array}{l}\text { 3.) A GYED a gyermek } 2 \text { éves koráig folyósítható (majd } \\
\text { visszaállítják } 3 \text { éves korra) }\end{array}$ \\
\hline & & & 4.) TGYÁS és GYED jogosultsági szabályok változása \\
\hline \multirow[t]{3}{*}{2011} & \multirow[t]{3}{*}{3} & \multirow[t]{3}{*}{5.7} & $\begin{array}{l}\text { 1.) A GYES-nél } 3 \text { éves kortól teljes munkaidős } \\
\text { foglalkoztatás, 1 éves kortól részmunkaidős } \\
\text { foglalkoztatás }\end{array}$ \\
\hline & & & 2.) A családi adókedvezmény szabályainak változása \\
\hline & & & 3.) Új otthonteremtési támogatási rendelet \\
\hline 2012 & & 3 & \\
\hline 2013 & & 0.9 & \\
\hline \multirow[t]{2}{*}{2014} & \multirow[t]{2}{*}{2} & \multirow[t]{2}{*}{2} & $\begin{array}{l}\text { 1.) GYES/GYED: teljes munkaidős foglalkoztatás a } \\
\text { gyermek } 1 \text { éves korától, részmunkaidős foglalkoztatás } \\
\text { 1 éves kortól engedélyezett }\end{array}$ \\
\hline & & & 2.) Diplomás GYED, GYED Extra \\
\hline 2015 & & 1.2 & \\
\hline \multirow{3}{*}{2016} & \multirow[t]{3}{*}{4} & \multirow[t]{3}{*}{4.6} & $\begin{array}{l}\text { 1.) GYES/GYED: teljes munkaidős foglalkoztatás a } \\
\text { gyermek } 1 \text { éves korától, részmunkaidős foglalkoztatás } \\
\text { 0,5 éves kortól engedélyezett }\end{array}$ \\
\hline & & & 3.) A családi adókedvezmény szabályainak változása \\
\hline & & & 4.) Új otthonteremtési támogatási rendelet \\
\hline 2017 & & 2.4 & \\
\hline 2018 & & 1.2 & \\
\hline
\end{tabular}

${ }^{a}$ Az első két évben nem rendelkezünk megfigyelésekkel a megelőző 3 évre vonatkozóan, így nem tudjuk kiszámítani a súlyozott átlagot. 


\section{IMPACT OF FAMILY POLICY MEASURES BETWEEN 2000 AND 2015 ON THE NUMBER OF BIRTHS IN HUNGARY}

\section{ABSTRACT}

This article analyzes the fertility effects of the Hungarian family policy system from 2000 to 2015, and we estimate panel fixed-effects models. Our results suggest that elements of the family policy system which enhance employment and dwelling probabilities or increase wages exert the most considerable effect on fertility. Accordingly, the current female employment status, childcare availability, and part-time employment opportunities effectively increase fertility. This finding is especially true for the bearing of the first child. The family policy system generally shows similar effectiveness as policies elsewhere; its overall fertility effect is slightly positive and significant. These results suggest that policies enhancing employment probabilities and increasing wages are probably among the most effective pro-fertility policies. Moreover, access to affordable dwelling is an important factor for fertility decisions, thus, this could be aided not only by supporting own flat purchases, but also by developing the rental housing market. 